\title{
Watsonella crosbyi from the lower Cambrian (Terreneuvian, Stage 2) Normanville Group in South Australia
}

\begin{tabular}{|c|c|}
\hline Journal: & Geological Magazine \\
\hline Manuscript ID & GEO-16-1471.R1 \\
\hline Manuscript Type: & Article \\
\hline Date Submitted by the Author: & 23-May-2016 \\
\hline Complete List of Authors: & $\begin{array}{l}\text { Jacquet, Sarah; Macquarie University, Department of Biological Sciences } \\
\text { Brougham, Tom; Macquarie University, Biological Sciences } \\
\text { Skovsted, Christian; Swedish Museum of Natural History, Palaeozoology } \\
\text { Jago, Jim; University of South Australia, School of Natural \& Built } \\
\text { Environment } \\
\text { Laurie, John; Geoscience Australia } \\
\text { Betts, Marissa; Macquarie University, Department of Biological Sciences } \\
\text { Topper, Timothy; Durham University, Department of Earth Sciences } \\
\text { Brock, Glenn; Macquarie University, Department of Biological Sciences }\end{array}$ \\
\hline Keywords: & $\begin{array}{l}\text { Normanville Group, }<\mathrm{i}>\text { Aldanella }</ \mathrm{i}>\text {, biostratigraphy, } \\
<\mathrm{i}>\text { Sunnaginia }</ \mathrm{i}>\text {, Stansbury Basin }\end{array}$ \\
\hline
\end{tabular}




\section{Watsonella crosbyi from the lower Cambrian (Terreneuvian, Stage 2)}

\section{Normanville Group in South Australia}

3

4 Sarah M. Jacquet ${ }^{\mathrm{a} *}$, Thomas Brougham ${ }^{\mathrm{a}}$, Christian B. Skovsted ${ }^{\mathrm{b}}$, James B. Jago ${ }^{\mathrm{c}}$, John R.

5 Laurie $^{\mathrm{d}}$, Marissa J. Betts ${ }^{\mathrm{a}}$, Timothy P. Topper ${ }^{\mathrm{e}}$ and Glenn A. Brock ${ }^{\mathrm{a}}$

6

7 a Department of Biological Sciences, Macquarie University, Sydney, New South Wales, 82109 , Australia

9 b Department of Palaeobiology, Swedish Museum of Natural History, P.O. Box 50007, SE-

1010405 Stockholm, Sweden

11 c School of Natural and Built Environments, University of South Australia, Mawson Lakes,

12 SA 5095, Australia

13 d Geoscience Australia GPO Box 378 ACT, 2601, Canberra

14 e Palaeoecosystems Group, Department of Earth Sciences, Durham University, Durham, DH1 15 3LE, UK

16

17 *Corresponding author: sarah.jacquet@mq.edu.au

19 Running title: Watsonella crosbyi from Cambrian Stage 2 in Australia

Abstract

Correlation of early Cambrian strata is often confounded by provincialism of key fauna.

23 Hence, the widespread occurrence of the micromollusc Watsonella crosbyi Grabau, 1900 is an

24 important biostratigraphic signpost with potential for international correlation of early

25 Cambrian successions. Previous correlations of $W$. crosbyi from Australia (Normanville 
26 Group) suggested an Atdabanian- to Botoman-equivalent age. However, in the upper part of

27 the Mount Terrible Formation, stratigraphic ranges of W. crosbyi and Aldanella sp. cf.

28 golubevi overlap prior to the incoming of vertically burrowed 'piperock' which is indicative

29 of an age no earlier than Cambrian Stage 2. The stratigraphic range of $W$. crosbyi in the

30 Normanville Group, South Australia correlates with the ranges of the taxon in China, France,

31 Mongolia and Siberia (though not Newfoundland). The new Australian data adds further

32 support for considering the first occurrence of $W$. crosbyi a good potential candidate for

33 defining the base of Cambrian Stage 2. The stratigraphic range of $W$. crosbyi through the

34 lower Cambrian Normanville Group has been determined based on collections from measured

35 sections. Though rare, $W$. crosbyi is part of an assemblage of micromolluscs including

36 Bemella sp., Parailsanella sp. cf. murenica and a sinistral form of Aldanella (A. sp. cf. A.

37 golubevi). Other fauna present include Australohalkieria sp., Eremactis mawsoni,

38 chancelloriids and Cupitheca sp.

40 Keywords: Normanville Group, Aldanella, biostratigraphy, Sunnaginia, Stansbury Basin.

\section{Introduction}

43 The definition of the base of the early Cambrian Stage 2 of the Terreneuvian Series has

44 become a subject of considerable controversy, especially regarding the reliability and

45 biostratigraphic utility of the micromollusc Watsonella crosbyi Grabau, 1900. This taxon has

46 a widespread distribution, and can be correlated across pre-trilobitic successions of both

47 carbonate and siliciclastic facies in South China, Siberia, Mongolia, Avalonia, and west and

48 east Gondwana (Table 1, Supplementary Material at http://journals.cambridge.org/geo,

49 references therein). For this reason $W$. crosbyi has been suggested as a suitable index fossil for

50 global correlation of the as yet undefined Cambrian Stage 2 (Li et al. 2011; Peng \& Babcock, 
2011). Watsonella crosbyi often co-occurs with the dextrally coiled shells of the stem group

52

53 mollusc, Aldanella attleborensis (Shaler \& Foerste, 1888), which shares a similar

geographical distribution and has also been suggested as a potential candidate to define the base of Cambrian Stage 2 (Parkhaev, 2014).

Comprehensive regional biostratigraphic schemes are crucial for constraining local geo- and bioevents and for developing workable global correlations (Betts et al. in review). However, biostratigraphic correlation and concomitant temporal subdivision can be undermined by taphonomic and taxonomic inconsistencies, and the diachronism of First Appearance Data (FAD) (see discussion by Landing et al. 2013). These factors are especially evident in the earliest Cambrian, where many pre-trilobitic biotas (i.e. small skeletal fossils, archaeocyaths and acritarchs) exhibit strong provincialism and facies-controlled distribution (Landing et al. 2013). Consequently, there has been emphasis on chemostratigraphic methods (i.e. carbon and oxygen isotopes) in combination with $\mathrm{U} / \mathrm{Pb}$ zircon geochronology as an independent (or primary) means of global correlation (e.g. Maloof et al. 2010a; Kouchinsky et al. 2012; Landing et al. 2013; but see Parkhaev, 2014). Non-biostratigraphic methods have previously been suggested as supplementary proxies for calibration (e.g. the ZHUCE/ I'positive $\delta^{13} \mathrm{C}$ excursion above the incoming of Watsonella) (Li et al. 2011; Landing et al. 2013), although Landing et al. (2013) emphasizes integration of biostratigraphic and chemostratigraphic data. Maloof et al. (2010a) applied a multiproxy approach to constrain occurrences of skeletal metazoan taxa during the Terreneuvian Series using a $\delta^{13} \mathrm{C}_{\mathrm{CaCO} 3}$ age model calibrated with U/Pb ID-TIMS dates of zircons from five separate ash beds in Morocco (Maloof et al. 2005; Maloof et al. 2010b) and China. By assigning time bins in $2 \mathrm{Ma}$ intervals, first appearance data of Watsonella from sections in Siberia, Mongolia and China indicate a First Appearance Datum (FAD) no older than 
$76 \sim 530$ Ma within the Nemakit-Daldynian Stage of the Siberian regional timescale. Expanding

77 on this work, Landing \& Kouchinsky (2016) suggested that the lower occurrences of $W$.

78 crosbyi in South China, France and Avalonia, as well as in northern Siberia are approximately

79 coeval, within the late Fortunian.

80 Landing et al. (2013) proposed that the I'/L4/ZHUCE $\delta 13 \mathrm{C}$ positive excursion

81 occurring just above the first appearance of Watsonella crosbyi and Aldanella attleborensis

82 and the Skiagia ornata-Fimbrioglomerella membranacea acritarch, Zone represents the best

83 multi-proxy approach for defining the base of Cambrian Stage 2. The use of independent time

84 constraints as suggested by Landing et al. (2103) is the most workable means to more

85 accurately define this important Cambrian Stage boundary. However, it is important that all

86 chemostratigraphic signals (especially bulk rock) are carefully evaluated using robust

87 protocols to ensure they are not influenced by local depositional conditions, cryptic

88 disconformities (Parkhaev, 2014; Miall, 2014), alteration by fluid-rock interactions during

89 subaerial exposure, as well as by diagenesis in the vadose or phreatic zones (Kaufman \&

90 Knoll, 1995; Derry, 2010; Swart, 2015).

91 Tracking changes in ichnodiversity and ichnodisparity during the Ediacaran-Cambrian

92 transition has also proven an effective independent means of broadly correlating key phases of

93 the Cambrian radiation (Seilacher, 1956; Crimes, 1987; Seilacher et al. 2005; Màngano \&

94 Buatois, 2014). Trace fossils reveal two distinct phases in body-plan diversification and the

95 establishment of a Phanerozic-style ecological structure (Màngano \& Buatois, 2014). The

96 Fortunian Stage records a rapid diversification with a global maximum of 42 ichnogenera.

97 Extent of bioturbation was relatively low, and assemblages were dominated by horizontal

98 traces. The transition to Cambrian Stage 2 records a dramatic increase in maximum burrowing

99 depth and the appearance of vertical burrows, especially Skolithos and Diplocraterion

100 'piperock' (Màngano \& Buatois, 2014). Utility of ichnofossils for global chronostratigraphic 
101 schemes is problematic, particularly with respect to the Cambrian period (Babcock et

102 al. 2014, but see Landing et al. 2013). Their key limitation is a strong lithofacies

103 dependence, which is exemplified by the almost exclusive appearance of Skolithos in

104 moderate to high-energy near-shore clastic deposits (Desjardins et al. 2010, see table 1;

105 Màngano \& Buatois, 2014). Nevertheless, the diversity of ichnotaxa and changes in

106 burrow morphology may prove useful as a broad indicator of age in the absence of

107 SSFs (especially in siliciclastic-rich deposits), particularly 'piperock' style burrowing

108 that first appears within Cambrian Stage 2.

109 Documentation of stratigraphic ranges of taxa such as Watsonella crosbyi or

110 Anabarella attleborensis across multiple geographic regions and through various

111 carbonate and siliciclastic successions increases their potential as candidate index

112 fossils to define the base of Cambrian Stage 2. The final task is to integrate

113 biostratigraphic and chemostratigraphic data to build a consistent, robust time-

114 significant signature and to attempt to explain any differences in stratigraphic range

115 which may limit the stratigraphic utility of these taxa.

116 The occurrence of Watsonella crosbyi in Australia has long been recognized

117 (Daily, 1976a, b; Daily et al. 1976; Gravestock \& Shergold, 2001; Parkhaev in

118 Gravestock et al. 2001; Jenkins et al. 2002) but lack of formal documentation and

119 poorly understood stratigraphic context has led to confusion about the stratigraphic

120 range and consequently, the correlation of this taxon in Cambrian East Gondwana.

121 Landing et al. (2013) and Parkhaev (2014) suggested that the stratigraphic range of $W$.

122 crosbyi in Australia correlates with the Abadiella huoi trilobite Zone, in the basal part

123 of Cambrian Series 2, Stage 3 (broadly equivalent to the Atdabanian Stage in Siberia).

124 However, a new shelly fossil biostratigraphy for the lower Cambrian of South Australia

125 clearly indicates the strata hosting $W$. crosbyi are considerably older (Betts et al., in 
126 review; herein). The aim of this paper is to rigorously establish stratigraphic context of $W$.

127 crosbyi (and Aldanella sp. cf. golubevi) from measured stratigraphic sections through the

128 lower part of the Normanville Group on Fleurieu Peninsula, eastern Stansbury Basin, South

129 Australia. In addition, Watsonella crosbyi and Aldanella sp. cf. golubevi are formally

130 described and the stratigraphic ranges of other key SSF are reassessed.

\section{2. Geological setting and locality}

133 The lower Cambrian Normanville Group (Fig. 1) is a sedimentary package of mixed

134 carbonates, argillites and sandstones exposed along a $\sim 16 \mathrm{~km} \mathrm{NE-SW}$ trending coastal tract in 135 the Sellick Hill-Normanville area on Fleurieu Peninsula, $50 \mathrm{~km}$ south of Adelaide. Early

136 geological and stratigraphic investigations into the Cambrian rocks of this region include the

137 work of Howchin (1897) and Madigan $(1925,1927)$ with detailed mapping and stratigraphy

138 by Abele \& McGowan (1959) and Daily (1963, 1972, 1976b).

139 [insert Figure 1 here]

140 The Normanville Group consists of an approximately $1 \mathrm{~km}$ thick succession of

141 predominantly marine shelf to ramp/slope limestones and shales, with minor arkosic and

142 calcareous sandstones towards the base, and significant deposits of black, pyritic shale

143 towards the top. The entire succession represents a transgressive marine event (sequence set

144 C1 of Gravestock, 1995), beginning with a shallow subtidal environment at the base, followed

145 by a shallow shelf setting with archaeocyathan-microbial bioherms, through to a deep-water

146 environment and eventually a mudstone dominated, basinal setting at the top (Alexander \&

147 Gravestock, 1990; Jago et al. 1994; Gravestock \& Gatehouse, 1995; Gravestock et al. 2001;

148 Jenkins et al. 2002).

149 In their detailed study of the lithology and stratigraphy of lower Cambrian rocks in the

150 Normanville-Sellick Hill region, Abele \& McGowran (1959) recognised four distinct and 
151 predominantly calcareous units (in ascending order with true thickness); Wangkonda

152 Formation (110 m), Sellick Hill Formation (210 m), Fork Tree Limestone (300 m) and

153 Heatherdale Shale (300 m). Subsequently, Daily (1963) proposed the name Mount

154 Terrible Formation to define a $\sim 92 \mathrm{~m}$ thick package of dominantly clastic rocks resting

155 unconformably above the Ediacaran ABC Range Quartzite (Wilpena Group) and below

156 the Wangkonda Formation. The lower 'Hyolithes sandstone' of Abele \& McGowran

157 (1959, p. 304) originally placed within the Wangkonda Formation was recognized as

158 the top member of the Mount Terrible Formation by Daily (1963). Together, these five

159 lithostratigraphic units constitute the Normanville Group (Daily \& Milnes, 1973, p. 4),

160 which is overlain unconformably by the extensive greywackes and shales of the lower

161 Cambrian Kanmantoo Group (Haines et al. 2009; Jago et al. 2003).

162 Almost all of the fossil material described here comes from collections originally

163 made by the late Brian Daily (Section 1 in Fig. 1 = 'New Sellick Hill Road', now Main

164 South Road). Unfortunately, Daily (1963) did not provide details on the exact location

165 of his section through the Mount Terrible Formation. Despite changes caused by re-

166 alignment and widening of the Main South Road since the early 1960s, it is possible to

167 closely approximate the position of his stratigraphic section from his existing field

168 notebooks combined with detailed geological mapping by Abele \& McGowran (1959).

169 This clearly shows where the 'Hyolithes sandstone' (= upper member, Mount Terrible

170 Formation of Daily, 1963) intersects the Main South Road (Fig. 1). Daily's field

171 notebooks indicate some of his original sampling along the road section was about 0.8

$172 \mathrm{~km}$ NNE along strike in Mount Terrible Gully.

173 In an attempt to supplement the lithostratigraphic and palaeontological details

174 described by Daily (1963) another section (Section 2, Figs 1 and 2) was measured

175 through the Mount Terrible Formation outcropping along Old Sellicks Hill Road, 
176 immediately south of Sellick Hill Quarry and approximately $2.8 \mathrm{~km}$ NNE of Daily's original

177 section. Despite some minor differences in the thickness of the members, the lithologies are

178 remarkably similar (Fig. 1). Unfortunately, despite targeted sampling in the middle and upper

179 members, the section produced very little fossil material (Eremactis mawsoni Bengtson \&

180 Conway Morris in Bengtson et al., 1990, indeterminate chancelloriids and phosphatic tubes).

182 3. Lithostratigraphy

183 3.a. Mount Terrible Formation

184 Daily $(1963,1972,1976 a, b)$ recognized three informal members of the Mount Terrible

185 Formation. Whilst there is some variation in thickness of the members along strike (Fig. 1),

186 the characteristic lithofacies of all members as described by Daily $(1963,1972,1976 a, b)$ and

187 summarized by Gravestock \& Cowley (1995), Gravestock et al. (2001, p. 25) and Gravestock

188 \& Shergold (2001) are readily identified in the field.

189 The Mount Terrible Formation is interpreted to be part of a transgressive systems tract

190 (E1.0 of Zang et al. 2004), equivalent to the Uratanna sequence of Mount \& MacDonald

191 (1992). Despite original claims of conformity (Daily 1963, p. 595), there is clearly a

192 disconformable surface separating the lowest member of the Mount Terrible Formation from

193 the underlying quartzites of the Neoproterozoic ABC Range Quartzite (see also Thomson \&

194 Horwitz, 1961). The incised nature of the contact (later noted by Daily, 1976a, p. 48) and the

195 absence of late Ediacaran rocks between the ABC Range Quartzite and the lowest Cambrian

196 deposits (including the fossiliferous Ediacaran member in the Rawnsley Quartzite) in the

197 Flinders Ranges, indicate a considerable time gap at this stratigraphic level on the Fleurieu

198 Peninsula.

199

200

3.a.1. Basal member 
201 The lower member is a feldspathic to quartz-rich sandstone ranging from $12 \mathrm{~m}$ to $17 \mathrm{~m}$ thick,

202 characterized by thin, planar-tabular bed sets with scoured bases. The basal 3-4 $\mathrm{m}$ are

203 comparatively feldspathic, although each bed consists of medium to coarse-grained quartz-

204 feldspathic arenites with a pebbly, phosphatized base and a bioturbated pyritic siltstone top.

205 Low-angle cross-beds and concordant lineations indicate high-energy conditions in a

206 transgressive marine (possibly marginal marine) environment (Daily, 1963, 1976b;

207 Gravestock \& Shergold, 2001).

208 Microfacies reveal a coarse-grained sandstone, consisting of a moderately well

209 sorted mosaic of angular to sub-rounded grains ( $>1 \mathrm{~mm}$ across), predominantly quartz

210 and rare feldspar (plagioclase represents 5-10\% of the sample) (Fig. 2a-c). The grains

211 are either tightly packed with no obvious authigenic cement (Fig. 2a) or with a very

212 fine calcareous cement containing iron oxides (possibly hematite; Fig. 2b). The iron

213 oxides are concentrated in some areas to form a dark cement, red at the edges

214 (observable as framboidal clusters), or are coating the quartz grains and filling

215 intergranular spaces (Fig. 2b, c). Some beds (>30 mm thick) exhibit weakly graded

216 bedding, which coarsens upwards.

217 [insert Figure 2 here]

218 The sediments of the basal member fill small holes and fissures, presumably

219 erosional in origin, in the underlying Neoproterozoic Ediacaran ABC Range Quartzite

220 (Daily, 1976a). Bioturbation is evident in the pyritic siltstone at the top of the lower

221 member down to $5 \mathrm{~m}$ above its base (Daily, 1976a; Gravestock \& Shergold, 2001).

222

223 3.a.2. Middle member

224 The middle member ranges in thickness from $60 \mathrm{~m}$ to $67 \mathrm{~m}$ and comprises grey, highly

225 bioturbated and occasionally phosphatic to slightly ferruginized siltstones to very fine 
226 sandstones with weathered, elliptical caverns produced by dissolution of carbonate nodules

227 towards the top of the member. Daily (1963) reported the first shelly fossils (hyoliths) at $20 \mathrm{~m}$

228 above the base of the Main South Road section (Fig. 3) and imprints of indeterminate tubes at

$22925 \mathrm{~m}$ above the base, within bands of phosphatic shale (Callen, 1971; Daily, 1976a;

230 Gravestock \& Shergold, 2001). This package is interpreted as a highstand systems tract (Daily

231 et al. 1976; Gravestock \& Shergold, 2001).

232 Microfacies of the middle member show the transition to intense sediment mixing, with

233 the original fabric often impacted or destroyed by pervasive, mainly horizontal, bioturbation.

234 In some horizons the fine-grained mottled fabric is represented by uniform, sub-angular

235 quartz grains $(>125 \mu \mathrm{m})$ within a frequently hematite stained calc-silt matrix (Fig. $2 \mathrm{~d}$, e).

236 Fabrics unaffected by intensive bioturbation have repeated interlaminae (1-3 $\mathrm{mm}$ thick) which

237 are very fine-grained and quartz-rich, and fine upwards into homogenous silts and micrites

238 (Fig. 2g). Elongate to ovoid clasts within these laminae, often of different lithology to the

239 surrounding matrix, may be compressed infilled horizontal burrows (Fig. 2f).

$240 \quad$ [insert Figure 3 here]

241

242 3.a.3. Top member

243 In Daily's (1963) section on Main South Road, the top member consists of a 20-30 m package

244 of strongly cavernous, fine-grained calcareous sandstones with pyritic and argillaceous

245 siltstone interbeds. The same lithostratigraphic package in Section 2 (Fig. 3) only exposes the

246 basal beds followed by a $\sim 20$ m covered interval obscuring the contact with the overlying

247 Wangkonda Formation, suggesting the upper member could be slightly thicker than originally

248 measured by Daily (1963). The sandstone is bioturbated, with shelly fossils occurring as

249 phosphatic steinkerns located within a $6 \mathrm{~m}$ interval in Section 1 in a weathered band of muddy

250 calcareous siltstone (Daily, 1963, 1969; Gravestock \& Shergold, 2001) (Fig. 3). Microfacies 
251 display a predominantly homogeneous fabric of very fine sand- to silt-sized, moderately

252 rounded quartz grains (Fig. 2h, i). Hematite staining is pervasive but forms mainly as irregular

253 wavy solution seams and laminae throughout the unit (Fig. 2h, i).

254

255

\section{Biostratigraphy}

256

257

\section{4.a. Regional correlation}

4.a.1. Previous work

There has been considerable confusion regarding the age and correlation of the

259 Normanville Group in recent literature. Most contention is traced back to poorly

260 constrained biostratigraphy in the Sellick Hill Formation and the conformably

261 overlying Fork Tree Limestone. Alexander \& Gravestock (1990) conducted a thorough

262 sedimentological study of the Sellick Hill Formation and described five Facies

263 Associations (A to E; oldest to youngest) from coastal exposures along the Fleurieu

264 Peninsula. Although Alexander \& Gravestock (1990) reported the presence of trilobites

265 in Facies Association D of the Sellick Hill Formation, subsequent attempts to locate

266 trilobites in this unit have been unsuccessful. As far as is known there are no

267 substantiated records of trilobites from either the Sellick Hill Formation or the Fork

268 Tree Limestone. Archaeocyaths from the upper Sellick Hill Formation (Facies

269 Association D to E) and lower Fork Tree Limestone have previously been correlated

270 with the Atdabanian to Botoman Stages of Siberia (Debrenne \& Gravestock, 1990).

271 However, based on the shelly fossil data presented by Betts et al. (2015; in review) and

272 the data presented herein this correlation requires close investigation. Gravestock

273 (1984) and Kruse \& Shi (in Brock et al. 2000, p.14) indicate the oldest archaeocyaths

274 in the Arrowie Basin are equivalent to Daily's (1956) Faunal Assemblages 1-2 which

275 they suggest are late Atdabanian equivalent in age. However, difficulties including 
276 strong endemism (Kruse \& Shi in Brock et al. 2000) and identification of archaeocyaths

277 (Gravestock et al. 2001) remain a primary concern regarding their utility for regional

278 correlation (Jenkins et al. 2002; Peng et al. 2012).

279 Adding to the confusion surrounding the age of the Normaville Group succession are

280 the assemblage 'zones' (especially molluscan zones) erected by Gravestock et al. (2001)

281 based on drill cores and stratigraphic sections measured in the Stansbury Basin. Gravestock et

282 al. (2001) correlated the upper Wangkonda Formation and lower Sellick Hill Formation

283 (Facies Association A of Alexander \& Gravestock, 1990) with their Bemella communis zone

284 and the remainder of the Sellick Hill Formation (uppermost Facies Association A to C) to the

285 Stenotheca drepanoida zone. These molluscan zones were suggested to have an Atdabanian

286 age and to correlate with the Abadiella huoi (for discussion of genus see Paterson \& Brock,

287 2007, p. 127; Landing et al. 2013, p. 159) and Pararaia tatei trilobite zones of the Arrowie

288 Basin despite the fact that trilobites are completely unknown from the Wangkonda and Sellick

289 Hill formations. This correlation was reported in subsequent publications (e.g. Gubanov,

290 2002; Parkhaev et al. 2012; Landing et al. 2013). However, the molluscan biozones of

291 Gravestock et al. (2001) have very poorly defined boundaries and are based on poorly

292 preserved, long-ranging taxa. Close inspection of the data given by Gravestock et al. (2001)

293 reveals clear temporal discrepancies between the sections on the Yorke and Fleurieu

294 peninsulas (Betts et al. in review). For instance, Gravestock et al. (2001, p. 38) state that 'the

295 lower boundary of the Bemella communis 'zone' is established by the appearance of Bemella

296 communis... and Aroonia seposita' in the Aquitaine SYC-101 well, while in the SADME

297 Minlaton 1 drillhole, they state that the base of the B. communis zone is equivalent to the first

298 appearance of the index species only (p. 44). In fact, no species recorded in the B. communis

299 zone, not even the eponym, is common to all records of that zone. Indeed, the only species

300 representative of the B. communis zone in the Yalkalpo-2 drill core is Pelagiella subangulata 
301 (Tate, 1892), which is the eponym of the zone below the $B$. communis zone. The

302 holotype of B. communis (PIN 4664/1331) is a poorly preserved phosphatic steinkern

303 (Gravestock et al. 2001, pl. XXIX, fig 2a-c) from sample SH22 in Facies Association A

304 of the Sellick Hill Formation at a level taken to correspond to the boundary between the

305 B. communis and S. drepanoida zones.

\section{4.a.2. Current study}

308 Shelly fossils were recovered from two stratigraphic levels within the Mount Terrible

309 Formation: from the topmost silty-sandstone layer within the middle member, about $63 \mathrm{~m}$ 310 above the base of the section; and an approximately $4 \mathrm{~m}$ interval (at $79-83 \mathrm{~m}$ above the base

311 of the section) within the top member (=Section 1, Fig. 3). The fauna is composed mainly of

312 molluscs (W. crosbyi, Aldanella sp. cf. golubevi, Bemella sp., Parailsanella sp. cf. murenica

313 Zhegallo in Esakova \& Zhegallo, 1996), as well as Eremactis mawsoni Bengtson \& Conway

314 Morris in Bengtson et al., 1990, Australohalkieria sp., Hyolithellus micans Billings, 1871 and

315 Cupitheca sp. This assemblage represents the oldest known shelly fossil assemblage from

316 Australia. Micromolluscs $W$. crosbyi and A. sp. cf. A. golubevi are described in detail below

317 (5. Systematic palaeontology). Other faunal elements are illustrated for completeness, but

318 poor preservation precludes assignment to species for most taxa (Fig. 4).

319 [insert Figure 4 here]

$320 \quad$ The univalved molluscs Bemella sp. and W. crosbyi range from the middle

321 member of the Mount Terrible Formation (Fig. 3) into Facies Association C of the

322 Sellick Hill Formation (see Gravestock et al. 2001, fig. 17). Jenkins et al. (2002)

323 reported (but did not figure) Watsonella sibirica (Missarzhevsky, 1974) from the

324 middle member of the Mount Terrible Formation in a restudy of material collected by

325 Brian Daily. Watsonella sibirica is now considered a synonym of Watsonella crosbyi 
326 (Landing, 1989; Kouchinsky, 1999; Li et al. 2011; Devaere et al. 2013). The halkieriid

327 Australohalkieria sp. originally described (as Halkieria sp. A) by Bengtson et al. (1990, p.

328 77) is now known to range from the middle member of the Mount Terrible Formation up into

329 the Wangkonda Formation (Fig. 3; Bengtson et al. 1990, fig. 49A-I). The coeloscleritophoran

330 Eremactis mawsoni ranges from the middle member of the Mount Terrible Formation to

331 Facies Association D of the Sellick Hill Formation in the Normanville Group.

332 Regional correlation of the Mount Terrible Formation and lithostratigraphic

333 equivalents, including the Winulta Formation (Daily, 1990) in the western Stansbury Basin

334 (Yorke Peninsula) and at least, partially, the Uratanna Formation (Daily, 1973), in the

335 Arrowie Basin has been hampered by lack of fossils (Daily, 1972). Faunal ties between the

336 lowermost Cambrian units on Yorke and Fleurieu Peninsulas are limited to indeterminate,

337 long ranging hyoliths and chancelloriids. The enigmatic sabelliditids (organic-walled tubes)

338 were reported by Daily (1976a) from the Mount Terrible Formation (lower part of the top

339 member) and from the Uratanna Formation (lower 100-150 m) by Mount \& MacDonald

340 (1992), but these are taxonomically intractable and consequently difficult to utilize for

341 correlation.

342 The coarse-grained and intensely bioturbated facies of approximately the lowermost 60

$343 \mathrm{~m}$ of the Mount Terrible Formation was not conducive to preservation of shelly fossils. The

344 predominance of siliciclastics in the eastern Stansbury and the Arrowie basins explains the

345 absence of $W$. crosbyi and associated shelly taxa from these regions. Hence, the local first

346 occurrence and range of $W$. crosbyi in the Mt. Terrible Formation track lithofacies changes

347 into calcareous sandstone, so are clearly lithofacies-specific (see Jacquet et al. in prep). Hence

348 whilst the occurrence of $W$. crosbyi in the Mt. Terrible Formation is clearly within Stage 2,

349 this cannot be construed as necessarily correlating with the first appearance of the taxon on a

350 global scale. 
Siliciclastic depositional settings are often conducive to the preservation of trace

352 fossils. In the absence of diverse early Cambrian skeletal fauna, the potential for using

353 trace fossils for intra- and inter-basin correlation in South Australian successions has

354 long been recognized (Daily, 1972; Gravestock \& Shergold, 2001). The predominantly

355 shallow marine to sub-tidal siliciclastic strata of the basal Cambrian successions in

356 Australia record a transition from an assemblage dominated by shallow burrowing,

357 architecturally complex traces to one which is monospecific or of low-diversity and

358 characterized by significantly increased burrowing depth $(>1 \mathrm{~m})$ (Màngano \& Buatois,

359 2014). Màngano \& Buatois (2014) have demonstrated that a clear change in behavior

360 and benthic community structure, with the emergence of vertical U-shaped burrows

361 (with spreite) such as Diplocraterion, is widespread during the Cambrian Radiation.

362 Whilst bioturbation is pervasive in the middle member of the Mount Terrible

363 Formation, no ichnotaxa can be clearly identified. In contrast, trace fossils present in

364 the contemporaneous Uratanna Formation in the Arrowie Basin are well documented

365 and include important ichnogenera and species such as Trichophycus pedum (used to

366 define the Ediacaran-Cambrian boundary) and Rusophycus spp. in the uppermost part

367 (Daily, 1972, 1976a; Mount, 1989; Gravestock \& Cowley, 1995). These ichnotaxa also

368 extend into the lower Parachilna Formation (Jensen et al. 1998; Gravestock \&

369 Shergold, 2001). Trace fossils have also been reported from outcrop in the Winulta

370 Formation (Trichophycus pedum, Plagiogmus arcuatus and Diplocraterion sp.)

371 (Gravestock \& Shergold, 2001), the Arumbera Sandstone in the Amadeus Basin

372 (Rusophycus sp., T. pedum, Diplichnites sp. and Plagiogmus sp.) and the Mount

373 Baldwin Formation in the Georgina Basin (Bergaueria sp., Helminthopsis sp.,

374 Treptichnus sp. and Diplocraterion parallelum) (Glaessner, 1969; Daily, 1972;

375 Gravestrock \& Shergold, 2001). Diplocraterion burrows first appear in the sandy 
376 interbeds of the Wangkonda Formation on the Fleurieu Peninsula (Daily, 1976a), and traces

377 identified as D. paralellum are extremely abundant in beds in the lower part of the Parachilna

378 Formation in the Arrowie Basin (Gravestock \& Cowley, 1995; Màngano \& Buatois, 2014).

379 The global shift to an advection-dominated system resulting from deep-tiering benthic

380 communities forming straight and U-shaped burrow systems is characteristic of the

381 Terreneuvian, Stage 2 (Màngano \& Buatois, 2014, fig. 1). This provides some measure of

382 biostratigraphic control for the Mount Terrible Formation, with the first appearance of

383 Watsonella crosbyi below that of Diplocraterion piperock in the overlying Wangkonda

384 Formation thus indicating an interval broadly equivalent with Cambrian Stage 2.

385 Watsonella crosbyi was reported from two horizons in Facies Association A and C

386 respectively of the Sellick Hill Formation, which overlies the Wangkonda Formation

387 (Parkhaev in Gravestock et al. 2001, pl. XLII, figs 15-16). Revaluation of the taxa occurring

388 within the upper range of Watsonella crosbyi in the Sellick Hill Formation illustrated by

389 Gravestock et al. (2001) include Bemella communis Parkhaev in Gravestock et al. 2001, B.

390 incomparabilis Parkhaev in Gravestock et al., 2001, Obtusoconus brevis Zhegallo in Esakova

391 \& Zhegallo, 1996, Anuliconus truncatus Parkhaev in Gravestock et al., 2001, and

392 Australohalkieria parva (Conway Morris in Bengtson et al., 1990); most are represented by

393 incomplete steinkerns. These co-occurring taxa are either restricted to the Sellick Hill

394 Formation or they have very long stratigraphic ranges. The last occurrence of $W$. crosbyi low

395 in Facies Association C of the Sellick Hill Formation is approximately $\sim 50 \mathrm{~m}$ below the first

396 occurrence of the widespread tommotiid Sunnaginia imbricata Missarzhevsky in Rozanov et

397 al., 1969 which occurs through Facies Association C to E of the SHL section (Fig. 5).

398 [insert Figure 5 here]

399 New stratigraphic sections (SHL and FTL, Fig. 1) measured through upper Facies

400 Association C of the Sellick Hill Formation through the entire Fork Tree Limestone reveal 
401 shelly assemblages including Kulparina rostrata, Dailyatia ajax, D. macroptera and a

402 probable new species of the paterinid brachiopod, Askepasma. This assemblage

403 represents the Kulparina rostrata Zone, recently defined in the Arrowie Basin by Betts

404 et al. (in review), and entirely predates the incoming of trilobites. This strongly

405 supports a pre-trilobitic, Terrenuevian, Stage 2 age for all units of the Normanville

406 Group below the Heatherdale Shale.

407 The $300 \mathrm{~m}$ thick succession of deep-water, fine-grained siliciclastics of the

408 Heatherdale Shale overlies the Fork Tree Limestone. This unit is generally poorly

409 fossiliferous, although the presence of trilobites (Jago et al. 1984; Jenkins \& Hasenohr,

410 1989) and bivalved arthropods (Isoxys) (Jago et al. 2006; Paterson et al. 2010) suggests

411 a P. janeae Zone age for the upper part of the Heatherdale Shale.

412

413 4.b. Global Correlation

414 Daily $(1972,1976 a$ ) first suggested the Mount Terrible Formation could be correlated with

415 the Tommotian Stage of Siberia based on shelly faunas (including Watsonella) and sabellitids.

416 This view was later supported by Jenkins et al. (2002) who proposed that the occurrence of

$417 W$. sibirica $(=W$. crosbyi) in the middle member of the Mount Terrible Formation was

418 evidence of an early to middle Tommotian-equivalent age. Our correlation is mainly based on

419 the occurrence of Watsonella crosbyi and Aldanella sp. cf. golubevi as well as the shelly fauna

420 and trace fossils in overlying strata. Watsonella crosbyi is widely distributed in upper

421 Terreneuvian strata (discussed further below), and A. golubevi is known only from transitional

422 Fortunian-Stage 2 strata of Siberia. However, other species of Aldanella have longer

423 stratigraphic ranges in the Terreneuvian (Parkhaev \& Karlova, 2011; Parkhaev, 2014). Other

424 taxa recovered from the Mount Terrible Formation are long-ranging and are therefore less

425 useful for global correlation. However, the stratigraphic range of S. imbricata has previously 
426 been used to define a biozone in the pre-trilobite Bonavista Group in Newfoundland which

427 succeeds the Watsonella crosbyi Zone of the underlying Chapel Island Formation (Fig. 6)

428 (Landing, 1988; Landing et al. 1989; Palacios et al. 2011). Similarly, the interval with

429 Sunnaginia imbricata in Facies Association C though to E of the Sellick Hill Formation $(\sim 50$

$430 \mathrm{~m}$ above the last local appearance of W. crosbyi in the lower part of Facies Association C)

431 provides strong evidence that the Mount Terrible Formation represents the early part of

432 Cambrian Stage 2 (Fig. 6).

433 [insert Figure 6 here]

434 In connection with recent efforts to define the chronostratigraphic divisions of the

435 Cambrian period, the stratigraphic range of Watsonella crosbyi has been extensively studied.

436 Watsonella crosbyi is one of the most widely distributed shelly fossils in the early part of the

437 Cambrian period (Terreneuvian) with a near global distribution (Table 1, online

438 Supplementary Material) and has been suggested as a suitable index fossil to define the lower

439 boundary of the Cambrian Stage 2 (Terreneuvian Series) (Li et al. 2011; Peng \& Babcock,

440 2011). However, the utility of $W$. crosbyi for global correlation has also been questioned

441 because of the supposed long stratigraphic range of the taxon (Parkhaev et al. 2012; Landing

442 et al. 2013). Restudy of the stratigraphic range of $W$. crosbyi in France (Devaere et al. 2013),

443 Siberia (Landing \& Kouchinsky, 2016), Mongolia (Brasier et al. 1996) and Australia (herein)

444 suggests that it is restricted to early-middle Stage 2 (Fig. 6). However, in Avalonia, $W$.

445 crosbyi has been reported to range from Member 3 of the Chapel Island Formation $(W$.

446 crosbyi Zone) into the Fosters Point Formation (Camenella baltica Zone), in horizons

447 suggested to correlate with the first appearance of trilobites in Siberia (Landing, 1989;

448 Landing et al. 2013).

449 In Siberia, the first appearance of $W$. crosbyi has usually been suggested to coincide

450 with the base of the Tommotian Stage (Nochoroicyathus sunnaginicus Zone; Rozanov et al. 
451 2008). However, it has recently been shown that $W$. crosbyi occurs substantially below

452 the base of the Tommotian Stage in northern Siberia (Fig. 6) (Nagovitsyn et al. 2015;

453 Landing \& Kouchinsky, 2016). As a complication, the base of the Tommotian remains

454 poorly defined and is ultimately based on the simultaneous incoming of numerous taxa

455 coinciding with a hiatus at the base of the Pestrotsvet Formation in the stratotype

456 Dvortsy section in southern Siberia (Landing et al. 2013; Landing \& Kouchinsky, 457 2016).

458 The W. crosbyi Assemblage Zone in South China (Steiner et al. 2007; Li et al.

459 2011) is usually correlated with the basal Tommotian Stage of Siberia, although

460 Landing \& Kouchinsky (2016) suggest that it is better correlated with pre-Tommotian

461 strata in northern Siberia (the Ary-Mas-Yuryakh and Kotujkan River sections). The

462 stratigraphic range of $W$. crosbyi in Mongolia has also been controversial with some

463 authors correlating strata in the upper Bayan-Gol Formation containing $W$. crosbyi with

464 either the Adtabanian (Brasier et al. 1996; Landing et al. 2013) or Tommotian

465 (Esakova \& Zhegallo, 1996) stages of Siberia. These views have recently been

466 challenged by Smith et al. (2015) who argue that this interval is pre-Tommotian based

467 largely on new carbon chemostratigraphic isotope data. Similarly, in the Montagne

468 Noire of France, strata containing W. crosbyi have been correlated with the Botoman

469 (Kerber, 1988), Tommotian (Devaere et al. 2013) and pre-Tommotian stages of Siberia

470 (Landing \& Kouchinsky, 2016).

471 The global first appearance of $W$. crosbyi is now demonstrated to occur in strata

472 that predate the base of the Tommotian Stage of Siberia (as defined by the FAD of $N$.

473 sunnaginicus) based on carbon isotope stratigraphy from Mongolia, South China,

474 Siberia and Avalonia (Fig. 6) (Smith et al. 2015; Landing \& Kouchinsky 2016). In all

475 these regions, the FAD of $W$. crosbyi occur below significant positive $\delta^{13} \mathrm{C}$ excursions 
476 (L4 in China, Li et al. 2009; I' in Bol'shaya Kounamka and the Ary Mas Yuryakh section of

477 northern and eastern Siberia, Knoll et al. 1995, Kouchinsky et al. 2001, Landing \&

478 Kouchinsky, 2016; F in Mongolia, Brasier et al. 1996) which correlate with the 6p excursion 479 in Morocco following Maloof et al. (2010a).

480 Caution is advised when correlating carbon isotope curves between continents, 481 especially in the absence of comprehensive biostratigraphic data. Carbon isotope data are 482 lacking for strata containing $W$. crosbyi in the Montagne Noire of France, but the associated 483 fauna closely corresponds with that from the W. crosbyi Zone of South China (Devaere et al. 4842013 ) and thus is likely pre-Tommotian equivalent.

485 In Australia, the Mount Terrible Formation consists predominantly of siliciclastics and 486 hence is unsuitable for $\delta^{13} \mathrm{C}$ chemostratigraphic analyses. Betts et al. (2015, in prep) presented 487 preliminary carbon-isotope chemostratigraphy measured through the upper $62 \mathrm{~m}$ of the 488 Sellick Hill Formation, (Facies Association C to E) at the SHL section, Myponga (Fig. 1). 489 The isotopic curve has values from -2 to -4 per mil, presenting a distinctly negative trend 490 similar to the global Shiyantou carbon isotope excursion (SHICE) (Zhu et al. 2006). More 491 comprehensive sampling and isotopic analyses of carbonates from the Wangkonda and Sellick 492 Hill Formations above the Mount Terrible Formation on Fleurieu Peninsula will be presented 493 elsewhere.

494 The apparently disjunct occurrences of $W$. crosbyi in France (Kerber, 1988), Mongolia 495 (Brasier et al. 1996) and South Australia (Gravestock et al. 2001) have been used as 496 arguments for the supposed diachroneity of the FAD of W. crosbyi (Rozanov et al. 2008; 497 Parkhaev et al. 2012; Landing et al. 2013). However, revision of anomalous occurrences has 498 shown that the range of $W$. crosbyi correlates most closely with the late Nemakit-Daldynian 499 and early Tommotian Stage of Siberia (Devaere et al. 2013; Smith et al. 2015; herein). In fact, 500 the only area where $W$. crosbyi has a range that includes strata above the early Tommotian are 
501 in Avalonian Newfoundland. There, W. crosbyi is reported to have a $650 \mathrm{~m}$ thick

502 composite stratigraphic interval (Chapel Island to Fosters Point Formation; Landing,

503 1989; Landing et al. 2013). However, this range includes the unfossiliferous strata of

504 the Random Formation (Fig. 6). Based on the changes in the perceived stratigraphic

505 ranges and correlations of $W$. crosbyi in Mongolia, France, Siberia and Australia (see

506 above), the long stratigraphic range of the species in Avalonia seems to invite

507 reinvestigation, especially since the record of this taxon is largely based on relatively

508 poorly preserved specimens on bedding surfaces (Bengtson \& Fletcher, 1983).

509

510 5. Systematic Palaeontology

511 All specimens are housed in the palaeontological collections of the South Australian Museum

512 (Prefix SAM P).

513

514 Phylum MOLLUSCA Linnaeus, 1758

515 Class, Order and Family Unknown

516 Genus WATSONELLA Grabau, 1900

517 Type species. Watsonella crosbyi Grabau, 1900

518

519 Remarks. The orientation used here for descriptive purposes is that suggested by Devaere et

520 al. (2013, fig. 13.). Watsonella was described by Pojeta \& Runnegar (1976) as

521 'pseudobivalved' where presence of a dorsal ridge or groove (Fig. 6f, g, i, k, n) may represent

522 a variably preserved separation between the two 'pseudovalves', similar to more derived

523 rostroconchs.

524

Designation of Wastonella as the 'oldest known rostroconch' (Landing et al.

5251988 , p. 691) deserves reconsideration following new insights into shell 
526 microstructures preserved on phosphatic steinkerns. Similarities between shell microstructure

527 textures and their respective spatial distribution on the steinkerns of Anabarella and

528 Watsonella indicate a closer phylogenetic affiliation with bivalves (Kouchinsky, 1999; Carter,

529 2001). Only a few specimens described herein preserve the characteristic 'spiny'

530 microstructure (see Vendrasco et al. 2011a, pl. 6, figs. 1-2, pl. 7, fig. 2) near the dorsum and

531 step-like textures (see Vendrasco et al. 2011a, pl. 6, figs. 3, 4, pl. 7, fig. 1) on the valves,

532 although polygonal textures are not preserved (Fig. 6h). Comprehensive investigation of the

533 horizontally oriented blades imprinted on the shell surface of Anabarella and Watsonella

534 demonstrate an evolutionary progression towards the laminar structures present in the earliest

535 confirmed bivalves (Pojetaia and Fordilla) (Vendrasco et al. 2011a, b). Stratigraphically,

536 there is also a clear discrepancy in timing between the appearance of Watsonella and the

537 earliest undoubted rostroconchs (Vendrasco et al. 2011b). In addition, documentation of a

538 bivalved larval shell in a juvenile Watsonella specimen from Tommotian deposits in Yakutia,

539 Siberia (Dzik, 1994, fig. 12g) supports the hypothesis of a closer relationship with bivalves

540 and would serve to separate the genus from the rostroconchs. However, this feature is rarely

541 preserved and undivided or incompletely divided larval shells have also been reported in

542 Watsonella (Vendrasco et al. 2011b). Nevertheless, there is now mounting morphological,

543 microstructural and stratigraphic evidence to suggest that that Watsonella represents a stem

544 bivalve rather than an early rostroconch.

545

546 Watsonella crosbyi Grabau, 1900

547 Fig. 7a-n

548

5491900 Grabau, Watsonella crosbyi; p. 632, pl. 1, figs. 9a-g. 
5502013 Devaere, Clausen, Steiner, Álvaro \& Vachard; Watsonella crosbyi Grabau; p. 37 figs

551 14.1-33, 15.1-14. (Includes full synonymy).

552

553 Figured Material. Four internal moulds (SAM P53331-53335), with an additional 33

554 unfigured specimens.

555

556 Diagnosis. See Devaere et al. (2013, p. 40).

557

558 Description. Univalved (pseudobivalved), bilaterally symmetrical and laterally compressed

559 phosphatic steinkerns; subelliptical in lateral view. Steinkerns range from 0.9-2.7 $\mathrm{mm}$ in

560 length, $0.54-1.67 \mathrm{~mm}$ in height and $0.29-0.57 \mathrm{~mm}$ in width. Lateral surfaces nearly flat, but

561 more strongly convex near dorsum and posterior margin where these surfaces are conjoined.

562 In lateral view, dorsum variably convex, tending to be most strongly convex towards

563 posterior. Anterior extremity angular (Fig. 7a), broadly acute; posterior extremity with

564 strongly convex apex overhanging strongly concave subapical field; apertural margin tends to

565 be fairly evenly curved. In dorsal view, steinkerns elongate subelliptical to subrectangular,

566 with maximum width tending to be towards posterior (Fig. 7f, k, 1, n). Dorsum with narrow

567 median furrow (Fig. 7f, i, n) or very weak ridge (Fig. 7l) along dorsum midline, extending

568 from anterior extremity of shell to just near apex where it sometimes bifurcates (Fig. 7f, g, k).

569 Subapical field very short and poorly preserved in all specimens. Aperture long, slit-like,

570 width similar along entire length (Fig. 7b). In some specimens, what appear to be internal

571 imprints of concentric growth lines are present (Fig. 7a, e). There is also what appears to be

572 an impression of a lamellar texture on the lateral surface of one of the steinkerns (Fig. 7h).

573 [insert Figure 7 here]

574 
575 Remarks. Watsonella crosbyi has received thorough taxonomic revision (Parkhaev in

576 Gravestock et al. 2001; Li et al. 2011; Devaere et al. 2013). The material examined herein

577 closely resembles specimens described by Parkhaev (in Gravestock et al. 2001, Pl. XLII, figs

578 15-16) from the Sellick Hill Formation. Parkhaev (in Gravestock et al. 2001, p. 188)

579 distinguished the Sellick Hill Formation specimens from the Siberian species, Watsonella

580 sibirica (= Heraultia sibirica Missarzhevsky, 1974), based on its comparatively narrow

581 anterior aperture, flattened valves and 'less risen anterior margin of the aperture'. Jenkins et

582 al. (2002) reexamined material collected by Brian Daily from the Mount Terrible Formation

583 (most likely that documented in this paper), and referred the specimens to $W$. sibirica.

584 However, $W$. sibirica is now rightly regarded as a junior synonym of $W$. crosbyi (Li et al.

585 2011; Devaere et al. 2013) and the features used to delineate the species by Parkhaev (in

586 Gravestock et al. 2001) are considered to be within the range of intraspecific variation.

587 Similarly, Yu (2014) described and illustrated specimens of Watsonella yunnanesis (He and

588 Yang, 1982) from the Dahai Member of the Yuhucun Formation, East Yunnan, China, which

589 are also now considered to be synonymous with W. crosbyi (Li et al. 2011; Devaere et al.

590 2013). Yu (2014) distinguished the Chinese material from the type species based on its

591 smaller size, blunt rounded beak, longer and wider ventral, anterior and posterior gapes,

592 where the latter extends beyond the sub-apical shield and partially along the dorsum (Yu,

593 2014, fig. 5). However, these characteristics vary within the concept of the species (Li et al.

594 2011), including the extended posterior gape, which is most likely a feature caused by

595 secondary phosphatization (see Fig. 7d).

596

597 Stratigraphic Range in South Australia. Middle and top members of the Mount Terrible

598 Formation and Facies Association A to C of the Sellick Hill Formation, Normanville Group,

599 Fleurieu Peninsula, eastern Stansbury Basin. Terreneuvian, Stage 2. 
600

601 Order HELCIONELLIDA Geyer, 1994

602 Family ALDANELLIDAE Linsley \& Kier, 1984

603 Genus ALDANELLA Vostokova, 1962

604 Type species. Aldanella attleborensis (Shaler \& Foerste, 1888).

605

606 Aldanella sp. cf. golubevi Parkhaev, 2007

607 Fig. 7o-X

608

609

Figured Material. 7 figured steinkerns (SAM P53336-53341), with an additional 7 unfigured 610 specimens.

611

612 Description. Asymmetrical, sinistrally coiled low turbinate shell (Fig. 7o-v); up to $1.64 \mathrm{~mm}$ in 613 diameter (average $1.42 \mathrm{~mm}$ ), shell composed of 1.5-1.7 whorls expanding strongly, with last 614 whorl occupying $58 \%$ of the maximum shell diameter. Shell height $32 \%$ of maximum shell 615 diameter; spire flattened, projecting only slightly; apex rounded (Fig. 7w-x). Aperture ovate, 616 approximately 2.5 times as wide as high; upper margin flattened, lower margin slightly 617 convex (Fig. 7o-q, t), distal margin strongly curved. Umbilicus broadly concave. Faint, 618 shallow furrows, convex towards aperture are present on the upper surface of some specimens 619 (Fig. 7r).

620

621 Remarks. Steinkerns of Aldanella from South Australia all exhibit sinistral coiling (Fig. 7r-s, $622 \mathrm{u}-\mathrm{v})$, unlike the dextral coiling that normally characterizes the genus. Whether the shell is a 623 true mirror-image of the typical dextral form, or whether it is dextrally hyperstrophic is 624 unknown due to the poor preservation of diagnostic shell features, especially muscle scars. A 
625 'pathological' sinistrally coiled Aldanella was originally described by Golubev (1976, pl. 3,

626 fig. 13), and subsequently, an assemblage of sinistrally coiled Aldanella was reported by

627 Parkhaev (2007) from the western Anabar Region of the Siberian Platform. The identification

628 of this particular sinistral assemblage as stratigraphically isolated from other dextral species

629 of Aldanella in conjunction with it having a unique pointed apex, led Parkhaev (2007) to refer

630 the shells to a new species, $A$. golubevi. This taxon is known to co-occur with both $A$.

631 attleborensis and A. crassa in Fortunian - Stage 2 transitional beds of the eastern and western

632 Anabar Region (Golubev, 1976; Parkhaev \& Karlova, 2011).

633 The broad similarities between the South Australian material and Siberian sinistrally

634 coiled A. golubevi are limited to the tight coiling of the whorls, their strong expansion and the

635 low to almost flattened spire. These characteristics further distinguish this taxon from other

636 sinistral taxa attributed to the genera Barskovia Golubev, 1976 and Nomgoliella

637 Missarzhevsky, 1980, which otherwise possess more oval or rounded apertural cross-sections

638 respectively. Unfortunately, the diagnostic pointed apex of A. golubevi (Parkhaev, 2007, pl. 2,

639 figs 7, 10b) is not present in our collection (Fig. 7w-x), which consists exclusively of

640 steinkerns. Consequently, the South Australian material is cautiously compared with $A$.

641 golubevi.

642

643 Stratigraphic Range in South Australia. Top member, Mount Terrible Formation,

644 Normanville Group, Fleurieu Peninsula. Eastern Stansbury Basin; Terreneuvian, Stage 2.

645

646 6. Conclusion

647 Paucity of cosmopolitan, biostratigraphically significant shelly taxa hinders early Cambrian

648 global correlation. However, the micromollusc W. crosbyi is now known from China, France,

649 Siberia, Mongolia, Avalonia and Australia and provides a crucial biostratigraphic link 
650 between pre-trilobitic strata in disparate palaeocontinents. The revised interpretation of the 651 stratigraphic range of $W$. crosbyi in South Australia strongly suggests that it is restricted to 652 early Cambrian Stage 2 (Peng et al. 2012). In the Mount Terrible Formation, the stratigraphic range of Watsonella crosbyi 654 (including overlap with Aldanella sp. cf. golubevi) predates the incoming of 655 656 657 stratigraphic range of $W$. crosbyi in the Normanville Group is estimated as $\sim 244 \mathrm{~m}$ 660 (true thickness; per data in Alexander \& Gravestock, 1990; Gravestock et al. 2001; herein). Carbon isotope values through the Facies Association C to E of the Sellick Hill Formation are suggestive of the negative SHICE event, further supporting an

Diplocraterion piperock in the Wangkonda Formation. Furthermore, occurrence of $W$. crosbyi in South Australia predates the local appearance of Sunnaginia imbricata in the upper part of the overlying Sellick Hill Formation, which is succeeded by a fauna indicative of the pre-trilobitic Kulparina rostrata Zone (Betts et al. in review). The 665 strengthens the correlative value of $W$. crosbyi as an index fossil to define the base of 666 Cambrian Stage 2.

667 668 Acknowledgements. Thanks to Jim and Linda Stacey, for providing access to their Myponga 669 Beach property and Brendan Carruthers of Southern Quarries Ltd., manager of Sellick Hill 670 Quarry, for providing access for sampling. Special thanks go to Elinor Alexander (PIRSA) for 671 assistance in the field; Macquarie University Microscopy Unit for technical support with the 672 SEM facilities; Nathan Daczko for use of the petrographic (Nikon Eclipse 50ipol) 673 microscope; David Mathieson for acid processing and picking fossiliferous residues and Dean 674 Oliver for original drafting of Figure 1. Thanks to Artem Kouchinsky and Li Guoxiang for 
675 their constructive reviews. Funding for the project comes from and ARC Discovery Project $676 \# 129104251$ to GAB.

677

\section{References}

679 Abele, C. \& MCGowran, B. 1959. The geology of the Cambrian south of Adelaide (Sellick 680 Hill to Yankalilla). Transactions of the Royal Society of South Australia 82, 301-20.

681 AleXander, E. M. \& Gravestock, D. I. 1990. Sedimentary facies in the Sellick Hill

682 Formation, Fleurieu Peninsula, South Australia. Geological Society of Australia, Special 683 Publication 16, 269-289.

684 Babcock, L. E., Peng, S., Zhu, M., XiaO, S. \& Ahlberg, P. 2014. Proposed reassessment of 685 the Cambrian GSSP. Journal of African Earth Sciences 98, 3-10.

686 Bengtson, S. \& Fletcher, T. P. 1983. The oldest sequence of skeletal fossils in the Lower 687 Cambrian of southeastern Newfoundland. Canadian Journal of Earth Sciences 20, 525$688 \quad 36$.

689 Bengtson, S., Conway Morris, S., Cooper, B. J., Jell, P. A. \& Runnegar, B. N. 1990.

690 Early Cambrian fossils from South Australia. Memoirs of the Association of $691 \quad$ Australasian Palaeontologists 9, 1-364.

692 Betts, M. J., Brock, G. A., Jago, J. B., Paterson, J. R. \& Andrew, A. 2015. Integrated 693 shelly fossil biostratigraphy and carbon and oxygen chemostratigraphy: Applying a 694 multi-proxy toolkit to correlating the early Cambrian of South Australia. In AAPG-SEG $695 \quad$ International Conference \& Exhibition Melbourne.

696 Betts, M. J., Paterson, J. R., Jago, J. B., Jacquet, S. M., Skovsted, C. B., Topper, T. P. 697 \& BROCK, G. A. In review. New lower Cambrian shelly fossil assemblage zones in the 698 lower Hawker Group, Arrowie Basin, South Australia. Gondwana Research Focused 699 Reviews. 
700 Billings, F. G. S. 1871. On some new species of Palaeozoic fossils. Canadian naturalist and 701 geologist 6, 213-233.

702 Brasier, M. D., Shields, G., Kuleshov, V. N. \& Zhegallo, E. A. 1996. Integrated chemo703 and biostratigraphic calibration of early animal evolution: Neoproterozoic-early 704 Cambrian of southwest Mongolia. Geological Magazine 133, 445-85.

705 Brock, G. A., Engelbretsen, M. J., Jago, J. B., Kruse, P. D., Laurie, J. R., Shergold, J.

706 H., SHI, G. R. \& SoRAuF, J. E. 2000. Palaeobiogeographic affinities of Australian 707 Cambrian faunas. Memoirs of the Association of Australasian Palaeontologists 23, 1$708 \quad 61$.

709 CALlen, R. A. 1971. Sedimentary Phosphate Exploration. Part 2: The Cambrian and 710 Proterozoic of Fleurieu Peninsula, the Mount Lofty Ranges, and Yorke Peninsula. . 711 Mineral Resources Review, South Australia 130, 80-94.

712 CARTER, J. G. 2001. Shell and ligament microstructure of selected Silurian and Recent 713 palaeotaxodonts (Mollusca: Bivalvia). American Malacological Bulletin 16, 217-38.

714 Compston, W., Zhang, Z., Cooper, J., Ma, G. \& Jenkins, R. 2008. Further SHRIMP

715 geochronology on the early Cambrian of South China. American Journal of Science $716 \quad 308,399-420$.

717 CRIMES, P. T. 1987. Trace fossils and correlation of late Precambrian and early Cambrian 718 strata. Geological Magazine 124, 97-119.

719 DAILy, B. 1956. The Cambrian in South Australia. In El Sistema Cambrico, su 720 paleogeografia y el problema de su base, Report 20th International Geological 721 Congress, Mexico 2 (ed. J. Rodgers). pp. 91-147..

722 Daily, B. 1963. The fossilferous Cambrian succession on Fleurieu Peninsula, South 723 Australia. Records of the South Australian Museum 14, 579-602. 
724 DAILY, B. 1969. Fossiliferous Cambrian sediments and low-grade metamorphics, Fleurieu

725 Peninsula, South Australia. In Section 3-Geological Excursions Handbook (ed B.

726 Daily). p. 49-54. Adelaide: ANZAAS, 41 st Congress.

727 DAILY, B. 1972. The base of the Cambrian and the first Cambrian faunas. In Stratigraphic 728 problems of the Later Precambrian and Early Cambrian, Volume 1 (eds J. B. Jones \&

$729 \quad$ B. McGowran). pp. 13-41.

730 DAILY, B. 1973. Discovery and Significance of Basal Cambrian Uratanna Formation, Mt.

731 Scott Range, Flinders Ranges, South Australia. Search 4, $202-05$.

732 Daily, B. 1976a. New data on the base of the Cambrian in South Australia. Izvestiya 733 Akademii Nauk SSSR, Seriya Geologicheskaya 3, 45-52.

734 DAILY, B. 1976b. The Cambrian of the Flinders Ranges. In 25th International Geological 735 Congress, Excursion Guide 33A, Sydney. pp. 15-19.

736 DAILY, B. 1990. Cambrian stratigraphy of Yorke Peninsula. Geological Society of Australia, 737 Special Publication 16, 215-229.

738 Daily, B., Firman, J. B., Forbes, B. G. \& Lindsay, J. M. 1976. Geology. In Natural history

739 of the Adelaide Region (eds C. R. Twidale, M. J. Tyler \& B. P. Webb). p. 5-42.

$740 \quad$ Adelaide: Royal Society of South Australia.

741 DAILY, B. \& MiLneS, A. R. 1973. Stratigraphy, structure and metamorphism of the

742 Kanmantoo Group (Cambrian) in its type section east of Tunkalilla Beach, South

743 Australia. Transactions of the Royal Society of South Australia 97, 213-42.

744 Debrenne, F. \& Gravestock, D. I. 1990. Archaeocyatha from the Sellick Hill Formation and

745 Fork Tree Limestone on Fleurieu Peninsula, South Australia. Geological Societyof

746 Australia Special Publication 16, 290-309.

747 Derry, L. A. 2010. A burial diagenesis origin for the Ediacaran Shuram-Wonoka carbon

748 isotope anomaly. Earth and Planetary Science Letters 294, 152-62. 
749

750

751

752

753

754

755

756

757

758

759

760

761

762

763

764

765

766

767

768

769

770

771

772

Desjardins, P. R., Gabriela Mángano, M., Buatois, L. A. \& Pratt, B. R. 2010. Skolithos pipe rock and associated ichnofabrics from the southern Rocky Mountains, Canada: colonization trends and environmental controls in an early Cambrian sand-sheet complex. Lethaia 43, 507-28.

Devaere, L., Clausen, S., Steiner, M., Álvaro, J. J. \& Vachard, D. 2013. Chronostratigraphic and palaeogeographic significance of an early Cambrian microfauna from the Heraultia Limestone, northern Montagne Noire, France. Palaeontologia Electronica 16, 1-91.

DZIK, J. 1994. Evolution of 'small shelly fossils' assemblages of the early Paleozoic. Acta Palaeontologica Polonica 39, 247-313.

Esakova, N. V. \& Zhegallo, E. A. 1996. Biostratigraphy and fauna of Lower Cambrian of Mongolia. Sovmestnaya Rossiisko-Mongol'skaya Paleontologicheskaya Ekspeditsiya Trudy 46, 1-214.

GeYER, G. 1994. Middle Cambrian molluscs from Idaho and early conchiferan evolution. New York State Museum Bulletin 481, 69-86.

Glaessner, M. F. 1969. Trace fossils from the Precambrian and basal Cambrian. Lethaia 2, $369-93$.

Golubev, S. N. 1976. Ontogenetic Changes and Evolutionary Trends in the Early Cambrian Spiral Gastropods Pelagiellacea. Paleontological Journal 10, 143-49.

Grabau, A. W. 1900. Palaeontology of the Cambrian terranes of the Boston Basin. Occasional Papers of the Boston Society Natural History 4, 601-94.

GRAVESTOCK, D. I. 1984. Archaeocyatha from lower parts of the Lower Cambrian carbonate sequence in South Australia. Memoirs of the Association of Australasian Palaeontologists 3, 1-139. 
773 GRAVEstock, D. I. 1995. Chapter 7. Early and Middle Palaeozoic. In The geology of South

774 Australia. Volume 2: The Phanerozoic (eds J. F. Drexel \& W. V. Preiss). pp. 3-5. Mines

775 and Energy South Australia Bulletin 54.

776 Gravestock, D. I. \& COWLey, W. M. 1995. Arrowie Basin. In The geology of South

777 Australia. Volume 2: The Phanerozoic. (eds J. F. Drexel \& W. V. Preiss). pp. 20-31.

$778 \quad$ Mines and Energy South Australia Bulletin 54.

779 Gravestock, D. I. \& Gatehouse, C. G. 1995. Stansbury Basin. In The Geology of South

780 Australia. Volume 2: The Phanerozoic (eds J. F. Drexel \& W. V. Preiss). pp. 5-19.

$781 \quad$ Mines and Energy South Australia Bulletin 54.

782 GRAVEStOcK, D. I. \& ShERGOLD, J. H. 2001. Australian Early and Middle Cambrian

783 Sequence Biostratigraphy with Implications for Species Diversity and Correlation. In

784 Ecology of the Cambrian Radiation (eds A. Y. Zhuravlev \& R. Riding). p. 107-36. New

$785 \quad$ York: Columbia University Press.

786 Gravestock, D. I., Alexander, E. M., Demidenko, Y. E., Esakova, N. V., Holmer, L. E.,

787 Jago, J. B., Lin, T-R., Melnikova, L. M., Parkhaev, P. Y., Rozanov, A. Y.,

788 Ushatinskaya, G. T., Zang, W-L., Zhegallo, E. A. \& ZhuravleV, A. Y. 2001. The

789 Cambrian biostratigraphy of the Stansbury Basin, South Australia. Russian Academy of

790 Sciences, Transactions of the Palaeontological Institute. 344 pp.

791 GuBANOV, A. P. 2002. Early Cambrian palaeogeography and the probable Iberia-Siberia 792 connection. Tectonophysics 352, 153-68.

793 Haines, P. W., Turner, S. P., Foden, J. D. \& Jago, J. B. 2009. Isotopic and geochemical

794 characterisation of the Cambrian Kanmantoo Group, South Australia: implications for

795 stratigraphy and provenance. Australian Journal of Earth Sciences 56, 1095-110. 
796 He, T. \& YANG, X. 1982. Lower Cambrian Meishucun stage of western Yangtze stratigraphic

797 region and its small shelly fossils. Bulletin of the Chengdu Institute of Geology and

798 Mineral Resources. Chinese Academy of Geological Sciences 3, 69-95.

799 Howchin, W. 1897. On the occurrence of Lower Cambrian fossils in the Mount Lofty

$800 \quad$ Ranges. Transactions of the Royal Society of South Australia 21, 74-86.

801 Jago, J. B., Dyson, I. A. \& Gatehouse, C. G. 1994. The nature of the sequence boundary

802 between the Normanville and Kanmantoo Groups on Fleurieu Peninsula, South

803 Australia. Australian Journal of Earth Sciences 41, 445-53.

804 Jago, J. B., Gatehouse, C. G., AleXander, E.M. \& CoOPer, B. J. 2006. Cambrian of

805 Fleurieu Peninsula. In XI International Conference of the Cambrian Stage Subdivision

806 Working Group. (eds J. B. Jago \& W-L. Zang). pp. 13-20. Geological Society of

807 Australia, South Australia Division, Adelaide.

808 Jago, J. B., Gum, J. C., Burtt, A. C. \& Haines, P. W. 2003. Stratigraphy of the Kanmantoo

809 Group: a critical element of the Adelaide Fold Belt and the Palaeo-Pacific plate margin,

810 Eastern Gondwana. Australian Journal of Earth Sciences 50, 343-63.

811 Jago, J., Daily, B., Von Der Borch, C., Cernovskis, A. \& Saunders, N. 1984. First

812 reported trilobites from the Lower Cambrian Normanville Group, Fleurieu Peninsula,

813 South Australia. Transactions of the Royal Society of South Australia 108, 207-11.

814 JENKINS, R.J.F. \& HASENOHR, P., 1989. Trilobites and their trails in a black shale: early

815 Cambrian of the Fleurieu Peninsula, South Australia. Transactions of the Royal Society

$816 \quad$ of South Australia 113, 195-203.

817 Jenkins, R., COOPER, J. \& COMPSTON, W. 2002. Age and biostratigraphy of Early Cambrian

818 tuffs from SE Australia and southern China. Journal of the Geological Society 159, 645-

81958 
820 Jensen, S., Gehling, J. G. \& Droser, M. L. 1998. Ediacara-type fossils in Cambrian

$821 \quad$ sediments. Nature 393, 567-69.

822 Kerber, M. 1988. Mikrofossilien aus Unterkambrischen Gesteinen der Montagne Noire, $823 \quad$ Frankreich. Palaeontographica Abteilung A 202, 127-203.

824 Kaufman, A. J. \& Knoll, A. H. 1995. Neoproterozoic variations in the C-isotopic

825 composition of seawater: stratigraphic and biogeochemical implications. Precambrian

$826 \quad$ Research 73, 27-49.

827 Knoll, A. H., Grotzinger, J. P., Kaufman, A. J. \& Kolosov, P. 1995. Integrated

828 approaches to terminal Proterozoic stratigraphy: an example from the Olenek Uplift, 829 northeastern Siberia. Precambrian Research 73, 251-70.

830 Kouchinsky, A. V. 1999. Shell microstructures of the Early Cambrian Anabarella and

831 Watsonella as new evidence on the origin of the Rostroconchia. Lethaia 32, 173-80.

832 Kouchinsky, A., Bengtson, S., Missarzhevsky, V. V., Pelechaty, S., Torssander, P. \&

833 VAlKov, A. K. 2001. Carbon isotope stratigraphy and the problem of a pre-Tommotian $834 \quad$ Stage in Siberia. Geological Magazine 138, 387-96.

835 Kouchinsky, A., Bengtson, S., Runnegar, B., Skovsted, C., Steiner, M. \& Vendrasco, 836 M. 2012. Chronology of early Cambrian biomineralization. Geological Magazine 149, $837 \quad 221-51$.

838 LANDING, E. 1988. Lower Cambrian of eastern Massachusetts: stratigraphy and small shelly 839 fossils. Journal of Paleontology 62, 661-95.

840 LANDING, E. 1989. Paleoecology and distribution of the Early Cambrian rostroconch 841 Watsonella crosbyi Grabau. Journal of Paleontology 63, 566-73.

842 Landing, E., GeYer, G., Brasier, M. D. \& Bowring, S. A. 2013. Cambrian evolutionary 843 radiation: context, correlation, and chronostratigraphy - overcoming deficiencies of the 844 first appearance datum (FAD) concept. Earth-Science Reviews 123, 133-72. 
845 Landing, E. \& Kouchinsky, A. 2016. Correlation of the Cambrian Evolutionary Radiation:

846 geochronology, evolutionary stasis of earliest Cambrian (Terreneuvian) small shelly

847 fossil (SSF) taxa, and chronostratigraphic significance. Geological Magazine.

848 Landing, E., Myrow, P., Benus, A. P. \& Narbonne, G. M. 1989. The Placentian Series:

849 appearance of the oldest skeletalized faunas in southeastern Newfoundland. Journal of

$850 \quad$ Paleontology 63, 739-69.

851 Li, D. , Ling, H.-F., JiAng, S.-Y., PAN, J.-Y., Chen, Y.-Q., CAI, Y.-F. \& FENG, H.-Z. 2009.

852 New carbon isotope stratigraphy of the Ediacaran-Cambrian boundary interval from SW

853 China: implications for global correlation. Geological Magazine 146, 465-84.

854 Li, G., ZhaO, X., Gubanov, A. P., ZhU, M. \& NA, L. 2011. Early Cambrian Mollusc

855 Watsonella crosbyi: A Potential GSSP Index Fossil for the Base of the Cambrian Stage

856 2. Acta Geologica Sinica - English Edition 85, 309-19.

857 LinSLEY, R. M. \& KIER, W. M. 1984. The Paragastropoda: A proposal for a new class of

$858 \quad$ Paleozoic Mollusca. Malacologia 25, 241-54.

859 LinNAEUS, C. 1758. Systema Naturae per regna tria naturae: secundum classes, ordines,

860 genera, species, cum characteribus, differentiis, synonymis, locis. Editio decima,

861 reformata., 10 ed. Stockholm: Laurentius Salvius, 824 pp.

862 Madigan, C. T. 1925. The Geology of the Fleurieu Peninsula Part I - The coast from

863 Sellick's Hill to Victor Harbour. . Transactions of the Royal Society of South Australia

$864 \quad 49,198-212$.

865 Madigan, C. T. 1927. The geology of the Willunga Scarp. Transactions of the Royal Society

$866 \quad$ of South Australia 51, 398-409.

867 Maloof, A. C., Porter, S. M., Moore, J. L., DudÁs, F. Ö., Bowring, S. A., Higgins, J. A., 868 FIKE, D. A. \& EDDY, M. P. 2010a. The earliest Cambrian record of animals and ocean 869 geochemical change. Geological Society of America Bulletin 122, 1731-74. 
870 Maloof, A. C., Ramezani, J., Bowring, S. A., Fike, D. A., Porter, S. M. \& Mazouad, M.

8712010 b. Constraints on early Cambrian carbon cycling from the duration of the Nemakit-

872 Daldynian-Tommotian boundary $\delta 13 \mathrm{C}$ shift, Morocco. Geology 38, 623-26.

873 Maloof, A. C., Schrag, D. P., Crowley, J. L. \& Bowring, S. A. 2005. An expanded record

874 of Early Cambrian carbon cycling from the Anti-Atlas Margin, Morocco. Canadian

$875 \quad$ Journal of Earth Sciences 42, 2195-216.

876 MÁngano, M. G. \& Buatois, L. A. 2014. Decoupling of body-plan diversification and

877 ecological structuring during the Ediacaran-Cambrian transition: evolutionary and

878 geobiological feedbacks. Proceedings of the Royal Society of London B: Biological

$879 \quad$ Sciences 281, 1-9.

880 Miall, A. D. 2014. Updating uniformitarianism: stratigraphy as just a set of 'frozen

881 accidents'. In Strata and Time: Probing the Gaps in Our Understanding. (eds D. G.

882 Smith, R. J. Bailey, P. M. Burgess \& A. J. Fraser). pp. 11-36. Geological Society,

$883 \quad$ London, Special Publications, 404.

884 MissarzHEVSKY, V. V. 1974. New data on the oldest fossils of the early Cambrian of the

885 Siberian platform. In Biostratigraphy and Paleontology of the Lower Cambrian of

886 Europe and Northern Asia (eds I. T. Zhuravleva \& A. Yu. Rozanov). pp. 179-89.

887 Moscow: Nauka.

888 MissarzhevsKy, V. V. 1980. Early Cambrian Mongolian Hyolitha and Gastropoda.

889 Paleontological Journal 1, 18-25.

890 MounT, J. F. 1989. Re-evaluation of unconformities separating the" Ediacaran" and Cambrian

891 systems, South Australia. Palaios 4, 366-73.

892 Mount, J. F. \& MCDonald, C. 1992. Influence of changes in climate, sea level, and

893 depositional systems on the fossil record of the Neoproterozoic-Early Cambrian

894 metazoan radiation, Australia. Geology 20, 1031-34. 
895 Nagovitsin, K. E., Rogov, V. I., Marusin, V. V., Karlova, G. A., Kolesnikov, A. V.,

896 Bykova, N. V. \& GRAZHDANKIN, D. V. 2015. Revised Neoproterozoic and

897 Terreneuvian stratigraphy of the Lena-Anabar Basin and north-western slope of the 898 Olenek Uplift, Siberian Platform. Precambrian Research 270, 226-45.

899 Palacios, T., Jensen, S., Barr, S. M., White, C. E. \& Miller, R. F. 2011. New

900 biostratigraphical constraints on the lower Cambrian Ratcliffe Brook Formation,

901 southern New Brunswick, Canada, from organic-walled microfossils. Stratigraphy 8,

$902 \quad 45-60$.

903 PARKHAEV, P. Y. 2007. Shell chirality in Cambrian gastropods and sinistral members of the 904 genus Aldanella Vostokova, 1962. Paleontological Journal 41, 233-40.

905 PARKHAEV, P. Y. 2014. On the stratigraphy of Aldanella attleborensis-potential index species

906 for defining the base of Cambrian Stage 2. IGCP Project 591 Field Workshop, 102 -05.

907 PARKhaEV, P. Y. \& Karlova, G. A. 2011. Taxonomic revision and evolution of Cambrian

908 mollusks of the genus Aldanella Vostokova, 1962 (Gastropoda: Archaeobranchia).

$909 \quad$ Paleontological Journal 45, 1145-205.

910 Parkhaev, P., Karlova, G. \& Rozanov, A. 2012. Stratigraphic distribution of two potential

911 species for the GSSP of Cambrian Stage 2-Aldanella attleborensis and Watsonella

912 crosbyi. Journal of Guizhou University 29, 179-80.

913 Paterson, J. R. \& Brock, G. A. 2007. Early Cambrian trilobites from Angorichina, Flinders

914 Ranges, South Australia, with a new assemblage from the Pararaia bunyerooensis

915 Zone. Journal of Paleontology 81, 116-42.

916 Paterson, J. R., Edgecombe, G. D., García-Bellido, D. C., Jago, J. B. \& Gehling, J. G.

917 2010. Nektaspid arthropods from the lower Cambrian Emu Bay Shale Lagerstätte,

918 South Australia, with a reassessment of lamellipedian relationships. Palaeontology 53,

$919 \quad 377-402$. 
920 PENG, S. C. \& BABCOCK, L. E. 2011. Continuing progress on chronostratigraphic subdivision 921 of the Cambrian System. Bulletin of Geosciences 86, 391-96.

922 Peng, S., BABCock, L. E. \& CoOPer, R. A. 2012. The Cambrian Period. In The Geologic 923 Time Scale 2012 2-Volume Set, Volume 2 (ed F. M. Gradstein, Ogg, J. G., Schmitz, M., 924 \& Ogg, G.). pp. 437-88. Elsevier.

925 Pojeta, J. \& Runnegar, B. 1976. The Paleontology of Rostroconch Mollusks and the Early 926 History of the Phylum Mollusca. US Geological Survey Professional Paper 968, 1-88. 927 Rozanov, A. Y., Missarzhevsky, V. V., Volkova, N. A., Voronova, L. G., Krylov, I. N., 928 Keller, B. M., Korolyuk, I. K., Lendzion, K., Michniak, R., Pychova, N. G. \& 929

930

931

932

933

934

935 Runnegar, B. \& Pojeta, J. 1985. Origin and diversification of the Mollusca. In The

936 Mollusca (eds E. R. Trueman \& M. R. Clarke). Vol. 10: 1-57. Academic Press, Orlando.

937 SeILACHER, A. 1956. Der Beginn des Kambriums als biologische Wende. Neues Jahrbuch für 938 Geologie und Paläontologie, Abhandlungen 103, 155-80.

939 Seilacher, A., Buatois, L. A. \& Mángano, M. G. 2005. Trace fossils in the Ediacaran-

940 Cambrian transition: behavioral diversification, ecological turnover and environmental 941 shift. Palaeogeography, Palaeoclimatology, Palaeoecology 227, 323-56.

942 Shaler, N. S. \& Foerste, A. F. 1888. Preliminary description of North Attleborough fossils. 943 Harvard Museum of Comparative Zoology Bulletin 16, 27-41. 
944 Smith, E. F., Macdonald, F. A., Petach, T. A., Bold, U. \& Schrag, D. P. 2015. Integrated

945 stratigraphic, geochemical, and paleontological late Ediacaran to early Cambrian

946 records from southwestern Mongolia. Geological Society of America Bulletin, 1-28.

947 Steiner, M., Li, G., Qian, Y., ZHU, M. \& ERDTMAnN, B.-D. 2007. Neoproterozoic to Early

948 Cambrian small shelly fossil assemblages and a revised biostratigraphic correlation of

949 the Yangtze Platform (China). Palaeogeography, Palaeoclimatology, Palaeoecology

$950 \quad 254,67-99$.

951 SWART, P. K. 2015. The geochemistry of carbonate diagenesis: The past, present and future.

$952 \quad$ Sedimentology 62, 1233-304.

953 TAte, R. 1892. The Cambrian fossils of South Australia. Transactions of the Royal Society of

$954 \quad$ South Australia 15, 183-89.

955 Thomson, B. P. \& HoRwITZ, R. C. 1961. Cambrian-Pre-Cambrian unconformity in Sellick

956 Hill-Normanville area of South Australia. Australian Journal of Science 24, 40.

957 Vendrasco, M. J., CheCA, A. G. \& KouchinsKy, A. V. 2011a. Shell microstructure of the

958 early bivalve Pojetaia and the independent origin of nacre within the mollusca.

$959 \quad$ Palaeontology 54, 825-50.

960 Vendrasco, M. J., Kouchinsky, A. V., Porter, S. M. \& Fernandez, C. Z. 2011 b.

961 Phylogeny and escalation in Mellopegma and other Cambrian molluscs. Palaeontologia

$962 \quad$ Electronica 14, 11A1-44.

963 Vostokova, V. A. 1962. Cambrian gastropods from Siberian platform and Taimyr. Sbonik

964 statej po paleontologii i biostratigrafii 28, 51-74.

965 YANG, B. 2014. Cambrian small shelly fossils of South China and their application in

966 biostratigraphy and palaeobiogeography. In Department of Geosciences p. 164. Berlin:

967 Freie Universität Berlin Berlin. 
968 YU, W. 1987. Yangtze Micromolluscan fauna in Yangtze region of China with notes on

969 Precambrian-Cambrian boundary. In Stratigraphy and Palaeontology of Systemic

970 Boundaries in China. Precambrian-Cambrian boundary pp. 19-255. Nanjing University

$971 \quad$ Publishing House.

972 YU, W. 2014. On the Yangtzeconus priscus-Archaeospira ornata Assemblage (Mollusca) of

973 the Earliest Cambrian of China. Acta Geologica Sinica - English Edition 88, 1262-87.

974 Zang, W. L., Jago, J. B., AleXander, E. M. \& Paraschivoiu, E. 2004. A review of basin

975 evolution, sequence analysis and petroleum potential of the frontier Arrowie Basin,

976 South Australia. In Eastern Australian Basins Symposium II. (eds P. J. Boult, D. R.

977 Johns and S. C. Lang). pp. 243-56. Petroleum Exploration Society of Australia, Special

$978 \quad$ Publication.

979 ZHU, M.-Y., BABCOCK, L. E. \& PENG, S.-C. 2006. Advances in Cambrian stratigraphy and

980 paleontology: Integraging correlation techniques, paleobiology, taphonomy and

981 paleoenvironmental reconstruction. Palaeoworld 15, 217-22.

982

983 Table 1. Global occurrences of Watsonella crosbyi Grabau, 1900.

984

985 Fig. 1. Regional geological map of the Normanville Group between Sellick Hill-Normanville

986 along the Fleurieu Peninsula, South Australia. Measured stratigraphic sections indicated.

987

988 Fig. 2. Microfacies from Section 1 (base coordinates: $35^{\circ} 20^{\prime} 30.3^{\prime \prime S}: 138^{\circ} 28^{\prime} 39.0^{\prime \prime} \mathrm{E}$ ) of the

989 three members of the Mount Terrible Formation. (a-c) Basal member, feldspathic to quartz-

990 rich sandstone; a. $1.4 \mathrm{~m}$ above the base of the section (cross polarized light). b-c. $8.2 \mathrm{~m}$ above

991 the base of the section, arrows indicate framboidal clusters. (d-g) Middle member, bioturbated

992 siltstones to very fine sandstones, occasionally phosphatic to slightly ferruginised; d-e. $16.6 \mathrm{~m}$ 
993 above base of the section. f-g. $57.6 \mathrm{~m}$ above the base of the section, f. burrow, g. repeated

994 interlaminae. (h-i) Top member, fine-grained calcareous sandstones siltstone interbeds: h. 83

995 m above the base of the section (35²0'28.7"S: $\left.138^{\circ} 28^{\prime} 36.4^{\prime \prime E}\right)$. i. $100.4 \mathrm{~m}$ above base of the 996 section $\left(35^{\circ} 20^{\prime} 28.4^{\prime \prime} \mathrm{S}: 138^{\circ} 28^{\prime} 35.8^{\prime \prime} \mathrm{E}\right)$.

997

998 Fig. 3. Lithostraigraphic column and biostratigraphy of faunas from the Mount Terrible 999 Formation for Section 1 (after Gravestock \& Shergold, 2001, fig. 6.3) and Section 2. 1000

1001 Fig. 4. (a-b) Indeterminate chancelloriid sclerites. (a) SAM P53318, plan view. (b) SAM 1002 P53319, basal view. (c-f) Eremactis mawsoni Bengtson \& Conway Morris in Bengtson et al., 1003 1990. (c-d) SAM P53320. c. lateral view; d. oblique lateral view. (e-f) SAM P53321. e. lower 1004 surface; f. oblique view of foramen. (g-m) Australohalkieria sp. (g-h) SAM P53322, palmate 1005 sclerite. g. lateral view; h. lower surface. (i) SAM P53323, palmate sclerite, lower surface. (j1006 k) SAM P53324, cultrate sclerite. j. lower surface; k. upper surface. (1-m) SAM P53325, top 1007 member of the Mount Terrible Formation; cultrate sclerite. 1. upper surface; m. lateral view. 1008 (n-r) Bemella sp. (n-o) SAM P53326. n. lateral view; o. apical view. (p-r) SAM P53327. p. 1009 supra-apical view; q. lateral view; r. apical view. (s-u) Parailsanella sp. cf. murenica

1010 Zhegallo in Esakova \& Zhegallo, 1996, SAM P53328. s. apical view; t. lateral view; u. supra1011 apical view. (v-w) Cupitheca sp. (v) SAM P53329. (w) SAM P53330.

1012

1013 Fig. 5. Sunnaginia imbricata Missarzhevsky in Rozanov et al., 1969 from the Sellick Hill

1014 Formation (SHL section base coordinates: 35²2'36.30"S; 138 $22^{\prime} 5.30^{\prime \prime} \mathrm{E}$ ); scale bars=200

$1015 \mu \mathrm{m} .(\mathrm{a}, \mathrm{b})$ Dextral sclerites from SHL/82.5, $56.3 \mathrm{~m}$ true thickness, Facies Association E; a.

1016 apical view, SAM P53342; b. apical view, SAM P53343. (c-f) Dextral sclerites from 
1017 SHL/50.9, 34.7 m true thickness, Facies Association D; c. apical view, SAM P53344; d.

1018 adapical view, SAM P53345; e. apical view, SAM P53346; f. adapical view, SAM P53347.

1019

1020 Fig. 6. Global chronostratigraphic correlation chart of Terreneuvian Series, Fortunian and

1021 Stage 2. Biostratigraphic and biozone data from Steiner et al. 2007, Kouchinsky et al. 2012,

1022 Devaere et al. 2013, Landing et al. 2013, Yang, 2014 (references therein) and Landing \&

1023 Kouchinsky, 2015. Isotopic data from Maloof et al. 2010a; and geochronological data from

1024 Maloof et al. $2010 a$ and Compston et al. 2008. Error bars have been included for SHRIMP

1025 dates.

1026

1027 Fig. 7. (a-n) Watsonella crosbyi Gabau, 1900, all specimens collected by Brian Daily from the

1028 middle member (3) of the Mount Terrible Formation, McGowran Locality, off Old Sellick

1029 Hill Road, Sellick Hill, Fleurieu Peninsula. (a-d) SAM P53331. a. lateral view; b. ventral

1030 view; c. magnification of apical area; d. posterior view. (e-i) SAM P 53332. e. lateral view,

1031 square shows location of h; f. dorsal view, squares show location of $\mathrm{g}$ and $\mathrm{i}$; g. magnification

1032 of diverging dorsal median furrow; h. magnification of lamella-fibrillar micro-ornamnet. (j-1)

1033 SAM P53333. j. lateral view; k. posterior view; 1. dorsal view. (m) SAM P53334, posterior

1034 view. (n) SAM P53335, dorsal view. (o-x) Aldanella sp. cf. golubevi, from the upper member

1035 of the Mount Terrible Formation. (o) SAM P53336, apertural view. (p) SAM P53337,

1036 apertural view. (q-r) SAM P53338. q. apertural view; r. spire view. (s-t, x) SAM P53339. s.

1037 spire view; t. apertural view; x. magnification of apex. (u) SAM P53340, spire view. (v-w)

1038 SAM P53341. v. spire view; w. magnification of apex. 


\section{Page 43 of 58}

\section{Proof For Review}

Fig. 1. Regional geological map of the Normanville Group between Sellick Hill-Normanville along the Fleurieu Peninsula, South Australia. Measured stratigraphic sections indicated. $170 \times 124 \mathrm{~mm}(300 \times 300 \mathrm{DPI})$ 
Fig. 2. Microfacies from Section 1 (base coordinates: $35^{\circ} 20^{\prime} 30.3^{\prime \prime} \mathrm{S}: 138^{\circ} 28^{\prime} 39.0^{\prime \prime} \mathrm{E}$ ) of the three members of the Mount Terrible Formation. (a-c) Basal member, feldspathic to quartz-rich sandstone; a. $1.4 \mathrm{~m}$ above the base of the section (cross polarized light). b-c. $8.2 \mathrm{~m}$ above the base of the section, arrows indicate framboidal clusters. (d-g) Middle member, bioturbated siltstones to very fine sandstones, occasionally phosphatic to slightly ferruginised; d-e. $16.6 \mathrm{~m}$ above base of the section. $\mathrm{f}-\mathrm{g} .57 .6 \mathrm{~m}$ above the base of the section, f. burrow, g. repeated interlaminae. (h-i) Top member, fine-grained calcareous sandstones siltstone interbeds: h. $83 \mathrm{~m}$ above the base of the section ( $35^{\circ} 20^{\prime} 28.7^{\prime \prime S}$ : $\left.138^{\circ} 28^{\prime} 36.4^{\prime \prime E}\right)$. i. $100.4 \mathrm{~m}$ above base of the section $\left(35^{\circ} 20^{\prime} 28.4^{\prime \prime} \mathrm{S}: 138^{\circ} 28^{\prime} 35.8^{\prime \prime} \mathrm{E}\right)$. $176 \times 391 \mathrm{~mm}(300 \times 300 \mathrm{DPI})$ 
Fig. 2. Microfacies from Section 1 (base coordinates: $35^{\circ} 20^{\prime} 30.3^{\prime \prime S}: 1^{\circ} 28^{\prime} 39.0^{\prime \prime E}$ ) of the three members of the Mount Terrible Formation. (a-c) Basal member, feldspathic to quartz-rich sandstone; a. $1.4 \mathrm{~m}$ above the base of the section (cross polarized light). b-c. $8.2 \mathrm{~m}$ above the base of the section, arrows indicate framboidal clusters. ( $\mathrm{d}-\mathrm{g}$ ) Middle member, bioturbated siltstones to very fine sandstones, occasionally phosphatic to slightly ferruginised; d-e. $16.6 \mathrm{~m}$ above base of the section. $\mathrm{f}-\mathrm{g} .57 .6 \mathrm{~m}$ above the base of the section, f. burrow, g. repeated interlaminae. (h-i) Top member, fine-grained calcareous sandstones siltstone interbeds: h. $83 \mathrm{~m}$ above the base of the section (35'20'28.7"S: $\left.138^{\circ} 28^{\prime} 36.4^{\prime \prime} \mathrm{E}\right)$. i. $100.4 \mathrm{~m}$ above base of the section $\left(35^{\circ} 20^{\prime} 28.4^{\prime \prime} \mathrm{S}: 138^{\circ} 28^{\prime} 35.8^{\prime \prime} \mathrm{E}\right)$. $176 \times 391 \mathrm{~mm}(600 \times 600 \mathrm{DPI})$
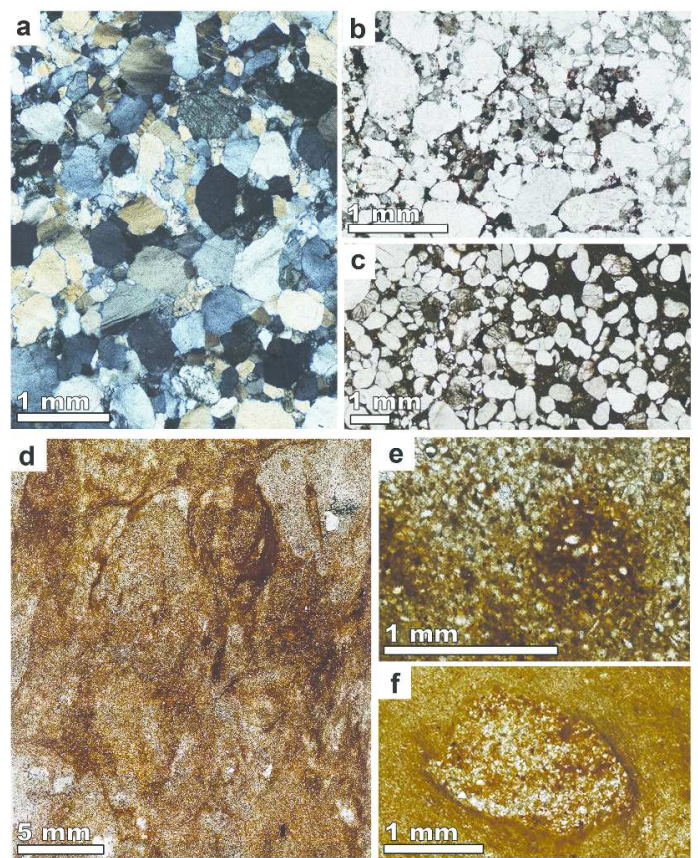

g
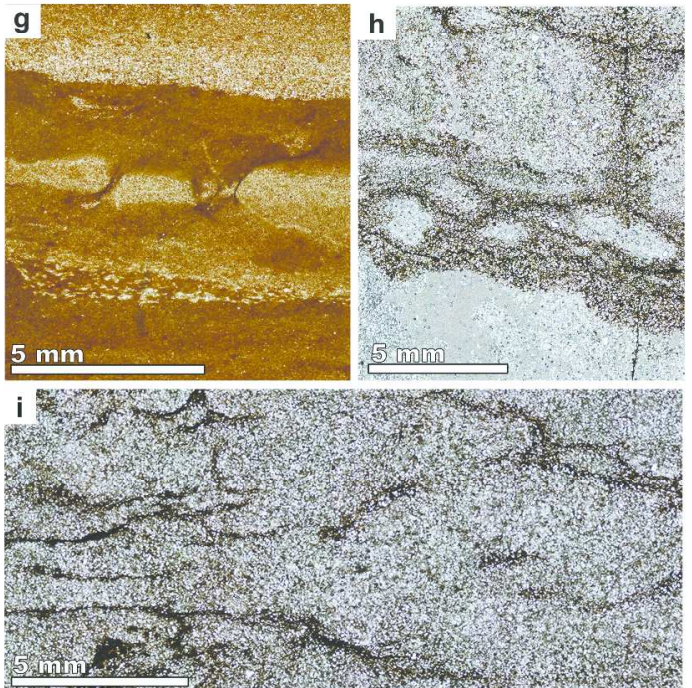

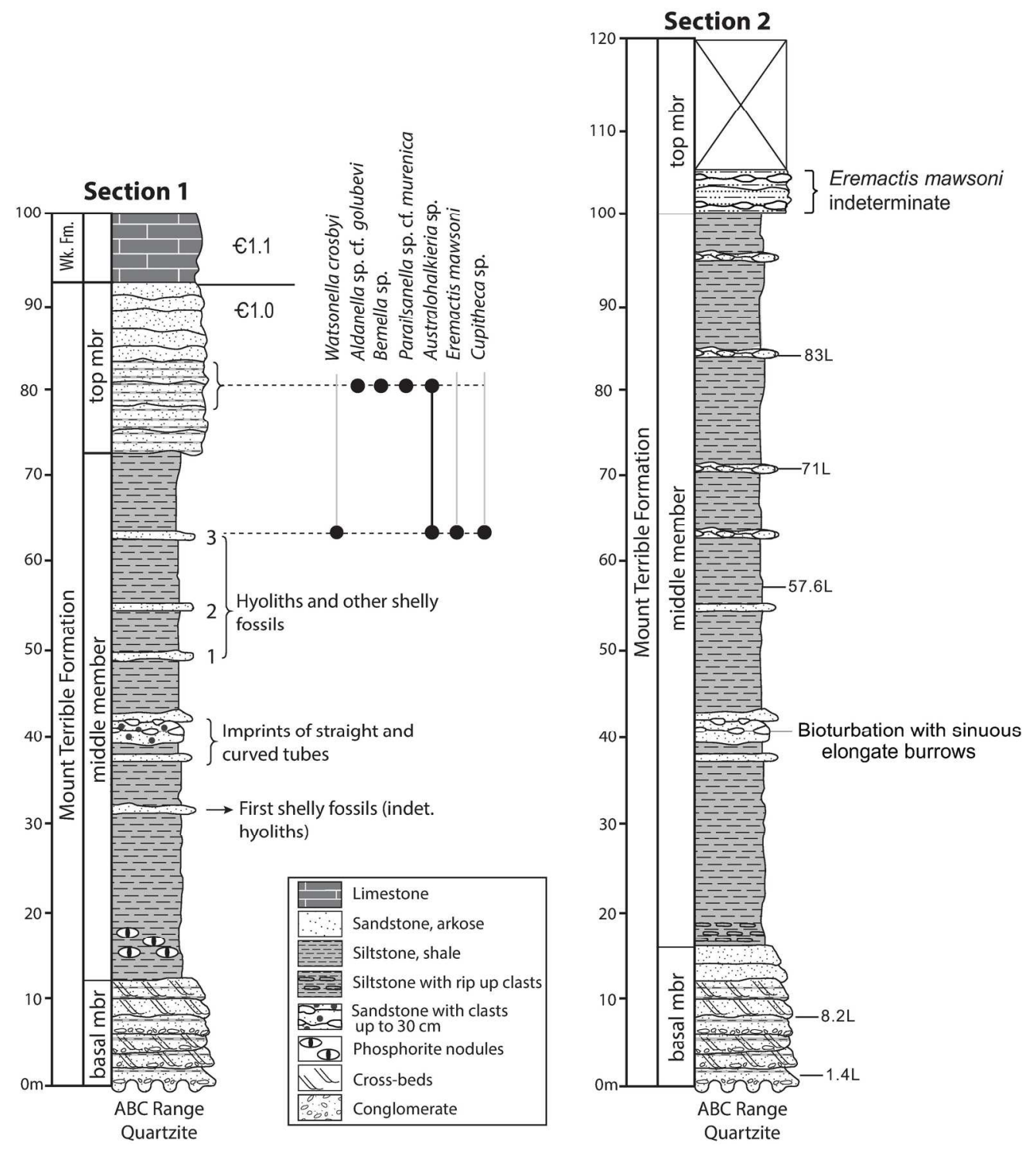

Fig. 3. Lithostraigraphic column and biostratigraphy of faunas from the Mount Terrible Formation for Section 1 (after Gravestock \& Shergold, 2001, fig. 6.3) and Section 2. $183 \times 207 \mathrm{~mm}(300 \times 300 \mathrm{DPI})$ 


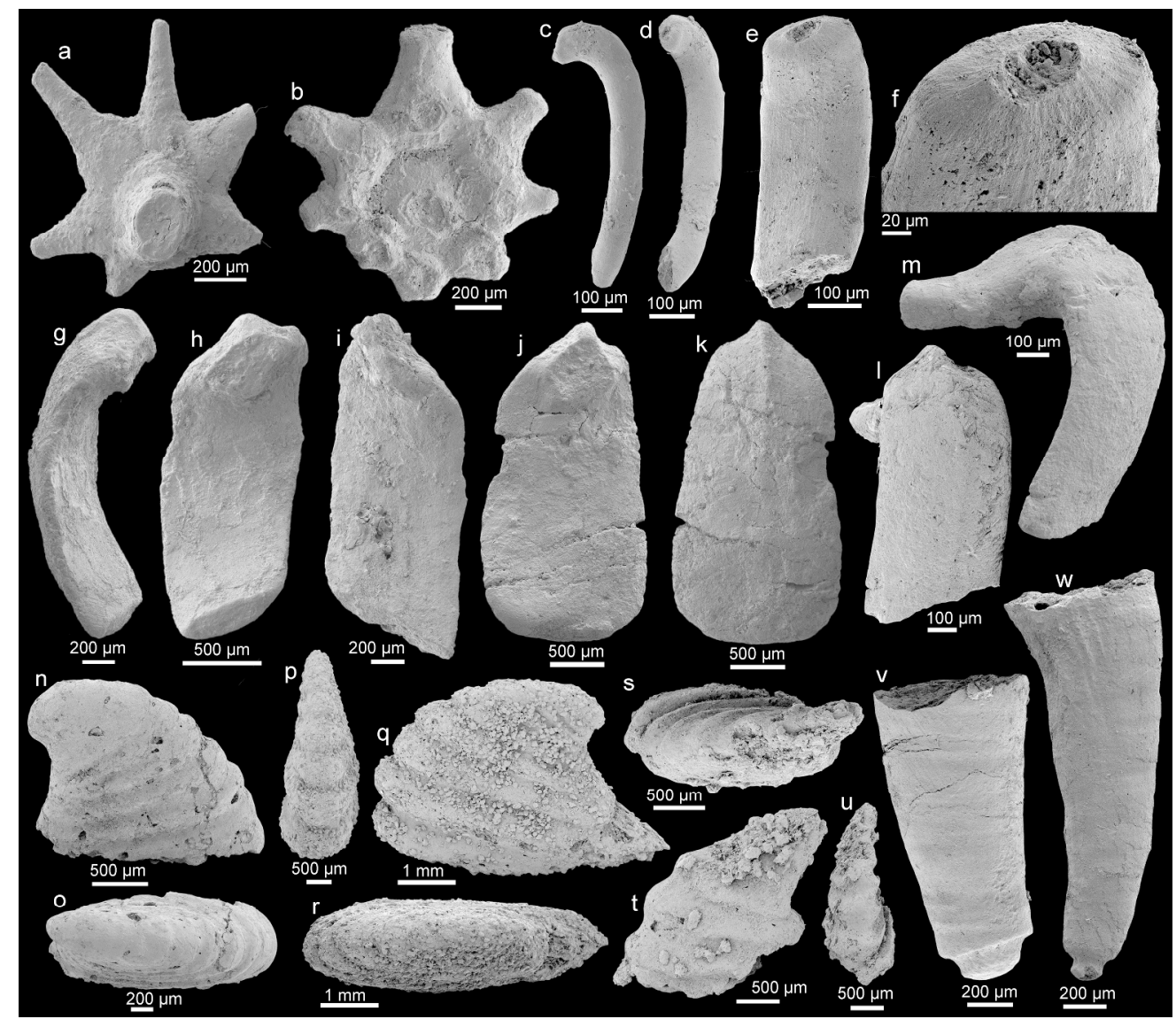

Fig. 4. (a-b) Indeterminate chancelloriid sclerites. (a) SAM P53318, plan view. (b) SAM P53319, basal view. (c-f) Eremactis mawsoni Bengtson \& Conway Morris in Bengtson et al., 1990. (c-d) SAM P53320. c. lateral view; d. oblique lateral view. (e-f) SAM P53321. e. lower surface; f. oblique view of foramen. (g-m) Australohalkieria sp. (g-h) SAM P53322, palmate sclerite. g. lateral view; h. lower surface. (i) SAM P53323, palmate sclerite, lower surface. (j-k) SAM P53324, cultrate sclerite. j. lower surface; k. upper surface. (I-m) SAM P53325, top member of the Mount Terrible Formation; cultrate sclerite. I. upper surface; m. lateral view. (n-r) Bemella sp. (n-o) SAM P53326. n. lateral view; o. apical view. (p-r) SAM P53327. p. supra-apical view; q. lateral view; r. apical view. (s-u) Parailsanella sp. cf. murenica Zhegallo in Esakova \& Zhegallo, 1996, SAM P53328. s. apical view; t. lateral view; u. supra-apical view. (v-w) Cupitheca sp. (v) SAM P53329. (w) SAM P53330. $147 \times 129 \mathrm{~mm}(600 \times 600 \mathrm{DPI})$ 


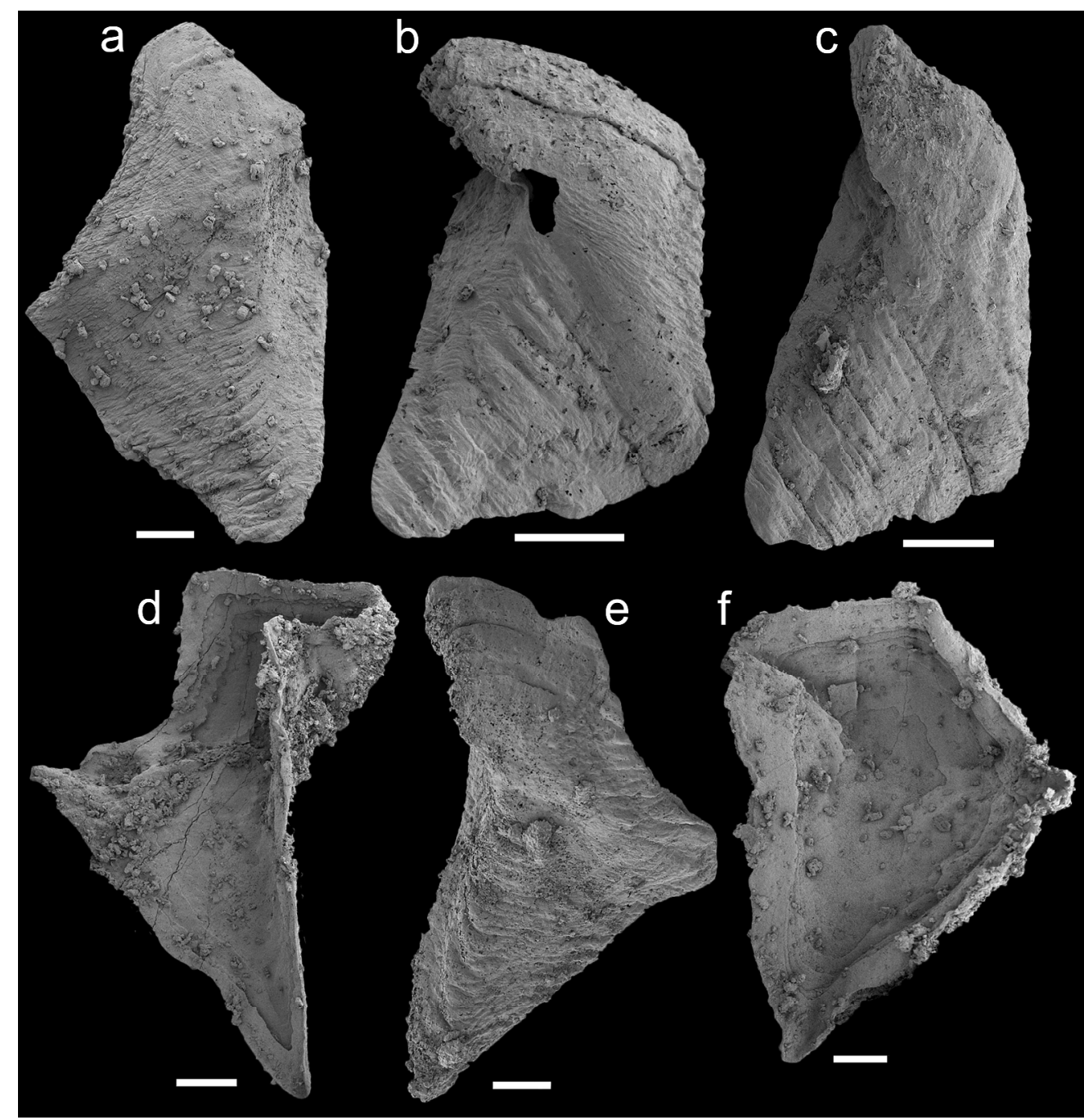

Fig. 5. Sunnaginia imbricata Missarzhevsky in Rozanov et al., 1969 from the Sellick Hill Formation (SHL section base coordinates: $\left.35^{\circ} 22^{\prime} 36.30^{\prime \prime} \mathrm{S} ; 138^{\circ} 22^{\prime} 5.30^{\prime \prime} \mathrm{E}\right)$; scale bars $=200 \mu \mathrm{m}$. (a, b) Dextral sclerites from $\mathrm{SHL} / 82.5,56.3 \mathrm{~m}$ true thickness, Facies Association E; a. apical view, SAM P53342; b. apical view, SAM P53343. (c-f) Dextral sclerites from SHL/50.9, $34.7 \mathrm{~m}$ true thickness, Facies Association D; c. apical view, SAM P53344; d. adapical view, SAM P53345; e. apical view, SAM P53346; f. adapical view, SAM P53347. 


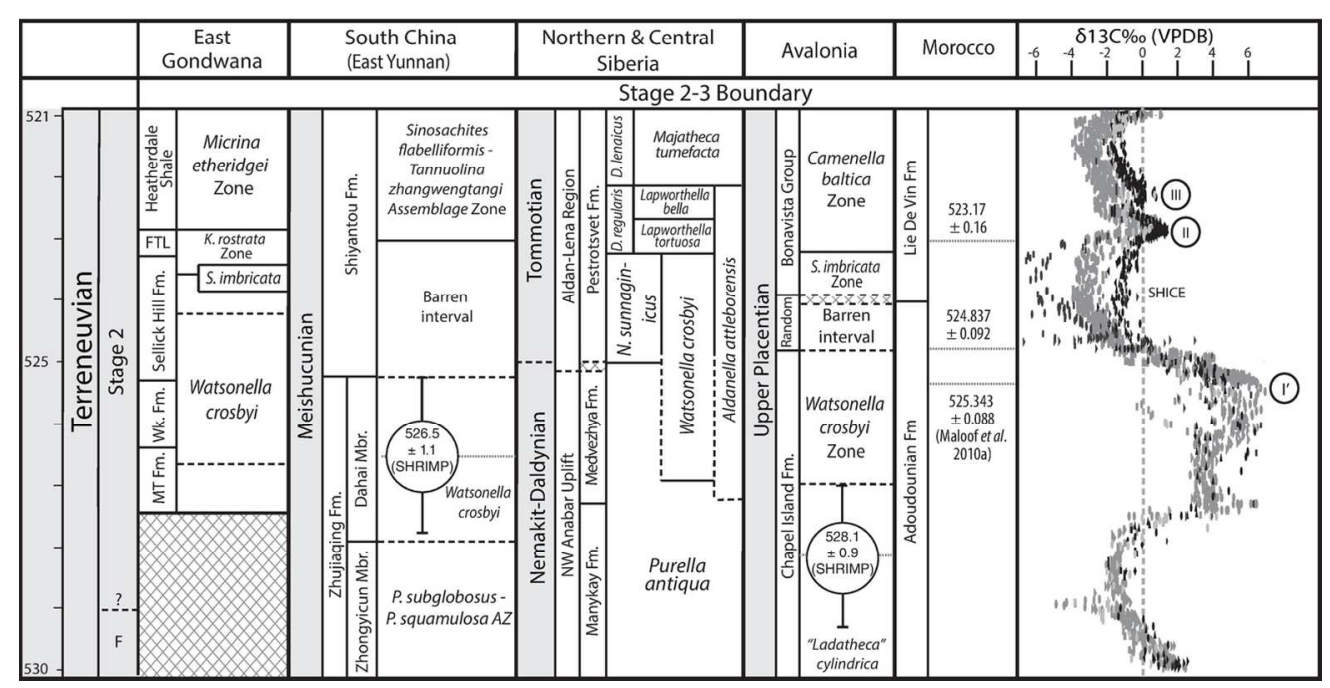

Fig. 6. Global chronostratigraphic correlation chart of Terreneuvian Series, Fortunian and Stage 2. Biostratigraphic and biozone data from Steiner et al. 2007, Kouchinsky et al. 2012, Devaere et al. 2013, Landing et al. 2013, Yang, 2014 (references therein) and Landing \& Kouchinsky, 2015. Isotopic data from Maloof et al. 2010a; and geochronological data from Maloof et al. 2010a and Compston et al. 2008. Error bars have been included for SHRIMP dates. $131 \times 103 \mathrm{~mm}(300 \times 300$ DPI) 


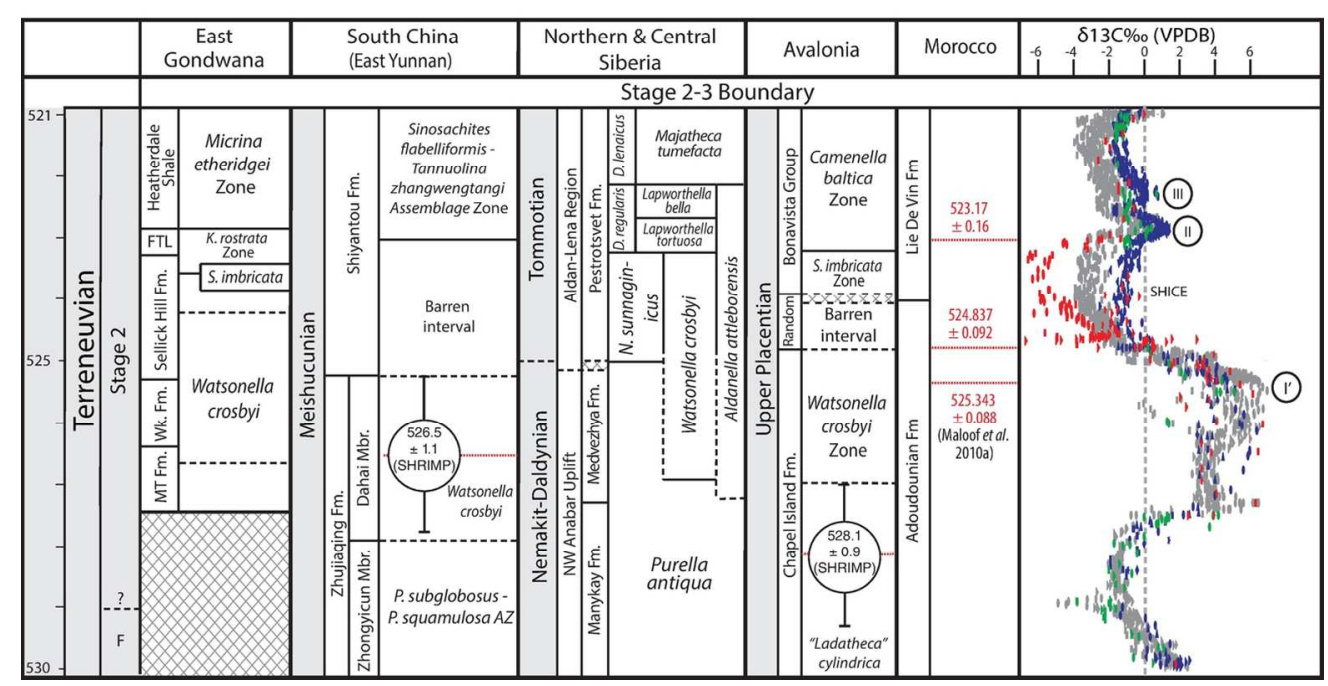

Fig. 6. Global chronostratigraphic correlation chart of Terreneuvian Series, Fortunian and Stage 2. Biostratigraphic and biozone data from Steiner et al. 2007, Kouchinsky et al. 2012, Devaere et al. 2013, Landing et al. 2013, Yang, 2014 (references therein) and Landing \& Kouchinsky, 2015. Isotopic data from Maloof et al. 2010a; and geochronological data from Maloof et al. 2010a and Compston et al. 2008. Error bars have been included for SHRIMP dates. $131 \times 103 \mathrm{~mm}(300 \times 300$ DPI $)$ 


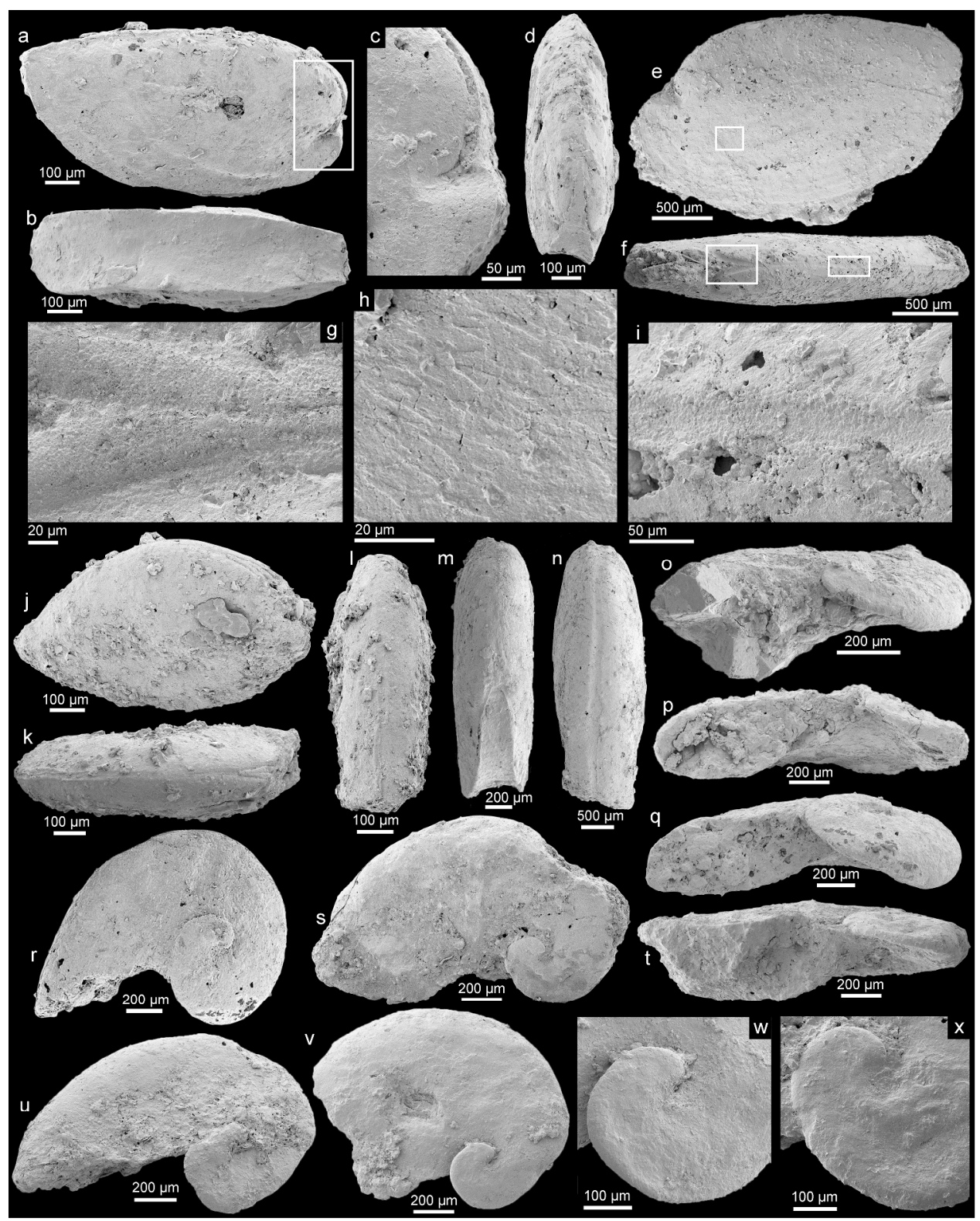

Fig. 7. (a-n) Watsonella crosbyi Gabau, 1900, all specimens collected by Brian Daily from the middle member (3) of the Mount Terrible Formation, McGowran Locality, off Old Sellick Hill Road, Sellick Hill, Fleurieu Peninsula. (a-d) SAM P53331. a. lateral view; b. ventral view; c. magnification of apical area; d. posterior view. (e-i) SAM P 53332. e. lateral view, square shows location of $h$; $f$. dorsal view, squares show location of $\mathrm{g}$ and $\mathrm{i}$; $\mathrm{g}$. magnification of diverging dorsal median furrow; h. magnification of lamella-fibrillar micro-ornamnet. (j-I) SAM P53333. j. lateral view; k. posterior view; I. dorsal view. (m) SAM P53334, posterior view. (n) SAM P53335, dorsal view. (o-x) Aldanella sp. cf. golubevi, from the upper member of the Mount Terrible Formation. (o) SAM P53336, apertural view. (p) SAM P53337, apertural view. (q-r) SAM P53338. q. apertural view; r. spire view. (s-t, $x$ ) SAM P53339. s. spire view; t. apertural view; $x$. magnification of apex. (u) SAM P53340, spire view. (v-w) SAM P53341. v. spire view; w. magnification of apex. 


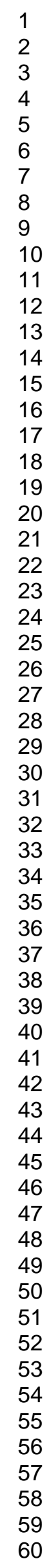




\section{Geological Magazine}

Watsonella crosbyi from the lower Cambrian (Terreneuvian, Stage 2) Mount Terrible Formation in South Australia

Sarah M. Jacquet, Thomas Brougham, Christian B. Skovsted, James B. Jago, John R. Laurie, Marissa J. Betts, Timothy P. Topper and Glenn A. Brock

Supplementary Material

Table 1. Global occurrences of Watsonella crosbyi Grabau, 1900.

\begin{tabular}{|c|c|c|c|c|c|}
\hline $\begin{array}{l}\text { Palaeo- } \\
\text { continents }\end{array}$ & 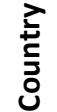 & $\begin{array}{l}\text { Geology and } \\
\text { Stratigraphy }\end{array}$ & Time interval & Biozone(s) & Source \\
\hline $\begin{array}{l}\text { South } \\
\text { China }\end{array}$ & $\stackrel{\frac{\pi}{5}}{\frac{\tilde{U}}{U}}$ & $\begin{array}{l}\text { Maidiping Formation, } \\
\text { Maidiping and Gaoqiao, } \\
\text { Emei County, Sichuan } \\
\text { Province } \\
\text { Maidiping Formation, } \\
\text { Hongzhai and Bangou, } \\
\text { Ganlu County, Sichuan } \\
\text { Province } \\
\text { Dahai Member, } \\
\text { Zhujiaqing Formation, } \\
\text { Dahai, Zhujiaqing and } \\
\text { Jiashewan, Huize } \\
\text { County, Yunnan Province } \\
\text { Dahai Member, } \\
\text { Zhujiaqing Formation, } \\
\text { Xiaotan, Yongshan } \\
\text { County, Yunnan Province } \\
\text { Dahai Member, } \\
\text { Zhujiaqing Formation, } \\
\text { Xianfeng and Baizai, } \\
\text { Xundian County, Yunnan } \\
\text { Province } \\
\text { Dahai Member, } \\
\text { Zhujiaqing Formation, } \\
\text { Laolin and Lishuping, } \\
\text { Huize County, Yunnan } \\
\text { Province } \\
\text { Dahai Member, } \\
\text { Zhujiaqing Formation, } \\
\text { Yulu, Huize County, } \\
\text { Yunnan Province } \\
\text { Meishucun Formation, } \\
\text { Meishucun, Jinning } \\
\text { County, Yunnan Province }\end{array}$ & Meishucunian & $\begin{array}{l}\text { Watsonella } \\
\text { crosbyi } \\
\text { Assemblage Zone } \\
\text { (Zone III) } \\
\text { Watsonella } \\
\text { crosbyi } \\
\text { Assemblage Zone } \\
\text { Watsonella } \\
\text { crosbyi } \\
\text { Assemblage Zone } \\
\text { Watsonella } \\
\text { crosbyi } \\
\text { Assemblage Zone } \\
\text { (Zone III) } \\
\text { Watsonella } \\
\text { crosbyi } \\
\text { Assemblage Zone } \\
\text { Watsonella } \\
\text { crosbyi } \\
\text { Assemblage Zone } \\
\text { (Zone III) } \\
\text { Watsonella } \\
\text { crosbyi } \\
\text { Assemblage Zone } \\
\text { Watsonella } \\
\text { crosbyi } \\
\text { Assemblage Zone }\end{array}$ & $\begin{array}{l}\text { Luo et al. 1982, 1984; } \\
\text { Yu, 1987; Qian, 1989; } \\
\text { Qian et al. 1996; Li et } \\
\text { al. } 2011 \\
\text { Qian, 1989; Li \& Xiao, } \\
\text { 2004; Steiner et al. } \\
\text { 2007; Li et al. 2011; } \\
\text { Yang, 2014 } \\
\text { Yu, 1987; Yang, } 2014\end{array}$ \\
\hline
\end{tabular}




\begin{tabular}{|l|l|l|l|}
$\begin{array}{l}\text { Upper Maidiping } \\
\text { Formation, Yangjiadun, } \\
\text { Eastern part of the } \\
\text { Yangtze Gorge, Yichang } \\
\text { County, Hubei Province }\end{array}$ & Meishucunian & $\begin{array}{l}\text { Watsonella } \\
\text { crosbyi } \\
\text { Assemblage Zone }\end{array}$ & Qian et al. 1979 \\
$\begin{array}{l}\text { Huangshandong } \\
\text { Member, Tongying }\end{array}$ & Meishucunian & $\begin{array}{l}\text { Watsonella } \\
\text { crosbyi }\end{array}$ & $\begin{array}{l}\text { Yu, 1987; Qian, 1989; } \\
\text { Li et al. 2011; Yu, 2014 }\end{array}$
\end{tabular}

Formation, Huangshandong, Yichang County, Hubei Province

Huangshandong Member, Tongying Formation, Tianzhushan, Yichang County, Hubei Province

\begin{tabular}{|c|c|c|c|c|c|}
\hline Avalonia & 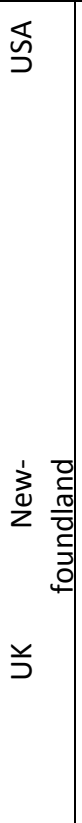 & $\begin{array}{l}\text { Red limestone boulders, } \\
\text { Weymouth Formation, } \\
\text { Sandy Cove and Pleasant } \\
\text { Beach, Cohasset, } \\
\text { Massachusetts } \\
\text { Lower Member, } \\
\text { Weymouth Formation, } \\
\text { Hoppin Reservoir, North } \\
\text { Attleboro area, } \\
\text { Massachusetts } \\
\text { Chapel Island Formation } \\
\text { to ?Fosters Point } \\
\text { Formation, Southeastern } \\
\text { Newfoundland } \\
\text { Home Farm Member } \\
\text { (Hyolithes Limestone), } \\
\text { Hartshill Formation, } \\
\text { Nuneaton, English } \\
\text { Midlands }\end{array}$ & $\begin{array}{l}\text { Upper Placentian } \\
\text { Comley }\end{array}$ & $\begin{array}{l}\text { Sunnaginia } \\
\text { imbricata - } \\
\text { Camenella baltica } \\
\text { Zone } \\
\text { Watsonella } \\
\text { crosbyi Zone } \\
\text { Watsonella } \\
\text { crosbyi Zone- } \\
\text { Camenella baltica } \\
\text { Zone } \\
\text { Camenella baltica } \\
\text { Zone }\end{array}$ & $\begin{array}{l}\text { Shaler \& Foerste, 1888; } \\
\text { Grabau, 1900; Pojeta \& } \\
\text { Runnegar, 1976; } \\
\text { Landing, } 1989 \\
\text { Landing, } 1988\end{array}$ \\
\hline $\begin{array}{l}\text { West } \\
\text { Gondwana }\end{array}$ & $\begin{array}{l}\stackrel{0}{U} \\
\frac{C}{0} \\
\frac{1}{4}\end{array}$ & $\begin{array}{l}\text { Heraultia Limestone, } \\
\text { Marcou Formation, } \\
\text { Montagne Noire }\end{array}$ & $\begin{array}{l}\text { No Stage } \\
\text { Subdivisions } \\
\text { [Tommotian } \\
\text { equivelant] }\end{array}$ & $\begin{array}{l}\text { Watsonella- } \\
\text { Oelandiella Zone }\end{array}$ & $\begin{array}{l}\text { Cobbold, 1935; } \\
\text { Runnegar \& Jell, 1976; } \\
\text { Pojeta \& Runnegar, } \\
\text { 1976; Runnegar \& } \\
\text { Pojeta, 1985; Kerber, } \\
\text { 1988; Devaere et al. } \\
2013\end{array}$ \\
\hline $\begin{array}{l}\text { Siberian } \\
\text { Platform }\end{array}$ & $\frac{\frac{\pi}{2}}{\frac{0}{d}}$ & $\begin{array}{l}\text { Lower reaches of Lena } \\
\text { River (no Formation } \\
\text { specified), northern } \\
\text { flanks of the Anabar } \\
\text { Uplift } \\
\text { Member IIIb, Kessyusia } \\
\text { Formation, Olenek } \\
\text { Uplift sections }\end{array}$ & $\begin{array}{l}\text { Tommotian } \\
\text { Tommotian }\end{array}$ & $\begin{array}{l}\text { No Biozone } \\
\text { specified } \\
\text { Nochoroicyathus } \\
\text { sunnaginicus } \\
\text { Zone }\end{array}$ & $\begin{array}{l}\text { Ushatinskaya \& } \\
\text { Parkhaev, } 2005 \\
\text { Khomentovsky \& } \\
\text { Karlova, 1993; } \\
\text { Kouchinsky, 1999 }\end{array}$ \\
\hline
\end{tabular}




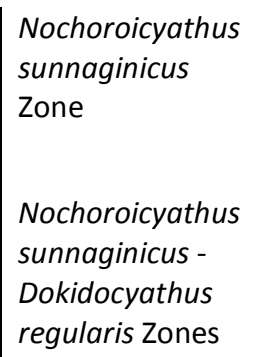

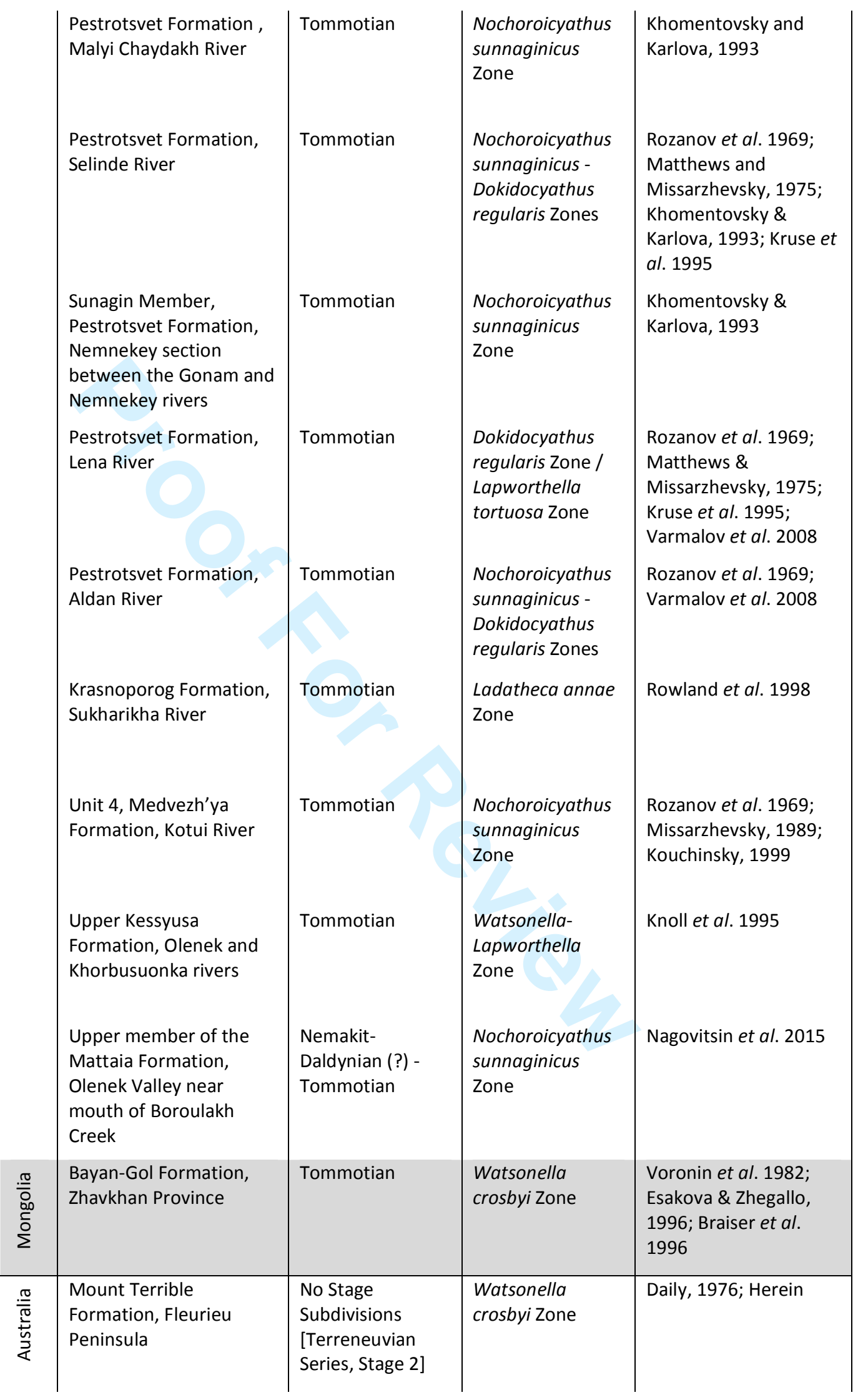


Facies Association A to $C_{1}$ Sellick Hill Formation

\section{References}

Bengtson, S. \& Fletcher, T. P. 1983. The oldest sequence of skeletal fossils in the Lower Cambrian of southeastern Newfoundland. Canadian Journal of Earth Sciences 20, 52536.

Brasier, M. D. 1984. Microfossils and small shelly fossils from the Lower Cambrian Hyolithes Limestone at Nuneaton, English Midlands. Geological Magazine 121, 22953.

Brasier, M. D., Shields, G., Kuleshov, V. N. \& Zhegallo, E. A. 1996. Integrated chemoand biostratigraphic calibration of early animal evolution: Neoproterozoic-early Cambrian of southwest Mongolia. Geological Magazine 133, 445-85.

CoBBold, E. S. 1935. Lower Cambrian from Herault, France. The Annals and Magazine of Natural History 16, 25-48.

DAILY, B. 1976. New data on the base of the Cambrian in South Australia. Izvestiya Akademii Nauk SSSR, Seriya Geologicheskaya 3, 45-52.

Devaere, L., Clausen, S., Steiner, M., Álvaro, J. J. \& Vachard, D. 2013. Chronostratigraphic and palaeogeographic significance of an early Cambrian microfauna from the Heraultia Limestone, northern Montagne Noire, France. Palaeontologia Electronica 16, 1-91.

Esakova, N. V. \& Zhegallo, E. A. 1996. Biostratigraphy and fauna of Lower Cambrian of Mongolia. Sovmestnaya Rossiisko-Mongol'skaya Paleontologicheskaya Ekspeditsiya Trudy 46, 1-214.

FENG, W. \& Sun, W. 2003. Phosphate replicated and replaced microstructure of molluscan shells from the earliest Cambrian of China. Acta Palaeontologica Polonica 48, 21-30.

Grabau, A. W. 1900. Palaeontology of the Cambrian terranes of the Boston Basin. Occasional Papers of the Boston Society Natural History 4, 601-94.

Gravestock, D. I., Alexander, E. M., Demidenko, Y. E., Esakova, N. V., Holmer, L. E., Jago, J. B., Lin, T.-R., Melnikova, L. M., Parkhaev, P. Y., Rozanov, A. Y., Ushatinskaya, G. T., Zang, W.-L., Zhegallo, E. A. \& Zhuravlev, A. Y. 2001. The Cambrian biostratigraphy of the Stansbury Basin, South Australia. Transactions of the Palaeontological Institute. $344 \mathrm{pp}$.

HE, T. \& YANG, X. 1982. Lower Cambrian Meishucun stage of western Yangtze stratigraphic region and its small shelly fossils. Bulletin of the Chengdu Institute of Geology and Mineral Resources. Chinese Academy of Geological Sciences 3, 69-95. 
JENKIns, R., COOPER, J. \& COMPSTON, W. 2002. Age and biostratigraphy of Early Cambrian tuffs from SE Australia and southern China. Journal of the Geological Society 159, 645-58.

Kerber, M. 1988. Mikrofossilien aus Unterkambrischen Gesteinen der Montagne Noire, Frankreich. Palaeontographica Abteilung A 202, 127-203.

Khomentovsky, V. V. \& Karlova, G. A. 1993. Biostratigraphy of the Vendian-Cambrian beds and the lower Cambrian boundary in Siberia. Geological Magazine 130, 29-45.

Knoll, A. H., Grotzinger, J. P., Kaufman, A. J. \& Kolosov, P. 1995. Integrated approaches to terminal Proterozoic stratigraphy: an example from the Olenek Uplift, northeastern Siberia. Precambrian Research 73, 251-70.

Kouchinsky, A. V. 1999. Shell microstructures of the Early Cambrian Anabarella and Watsonella as new evidence on the origin of the Rostroconchia. Lethaia 32, 173-80.

Kruse, P. D., Zhuravlev, A. Y. \& James, N. P. 1995. Primordial metazoan-calcimicrobial reefs: Tommotian (early Cambrian) of the Siberian platform. Palaios 10, 291-321.

LANDING, E. 1988. Lower Cambrian of eastern Massachusetts: stratigraphy and small shelly fossils. Journal of Paleontology 62, 661-95.

LANDING, E. 1989. Paleoecology and distribution of the Early Cambrian rostroconch Watsonella crosbyi Grabau. Journal of Paleontology 63, 566-73.

Landing, E., Myrow, P., Benus, A. P. \& Narbonne, G. M. 1989. The Placentian Series: appearance of the oldest skeletalized faunas in southeastern Newfoundland. Journal of Paleontology 63, 739-69.

LI, G. \& S., X. 2004. Tannuolina and Micrina (Tannuolinidae) from the Lower Cambrian of eastern Yunnan, south China, and their scleritome reconstruction. Journal of Paleontology 78, 900- 13.

Li, G., ZhaO, X., Gubanov, A. P., Zhu, M. \& NA, L. 2011. Early Cambrian Mollusc Watsonella crosbyi: A Potential GSSP Index Fossil for the Base of the Cambrian Stage 2. Acta Geologica Sinica - English Edition 85, 309-19.

Luo, H., Jiang, Z., Wu, X., Song, X., Ouyang, L., Xing, Y., Lui, G., Zhang, S. \& TaO, Y. 1982. The Sinian-Cambrian Boundary in Eastern Yunnan, China. Kunming: People's Publishing House of Yunnan. 265 pp.

LuO, H., JiAnG, Z. \& Wu, X. 1984. Sinian-Cambrian boundary stratotype section at Meishucun, Jinning, Yunnan, China. Kunming: Yunnan People's Publishing House. 154 pp.

Matthews, S. C. \& Missarzhevsky, V. V. 1975. Small Shelly Fossils of late Precambrian and early Cambrian age: a review of recent work. . Journal of the geological Society of London 131, 989-304.

MissarzheVsKy, V. 1989. The oldest skeletal fossils and stratigraphy of the PrecambrianCambrian boundary beds. Trudy Geologicheskogo Instituta AN SSSR 443, 1-237. 
Nagovitsin, K. E., Rogov, V. I., Marusin, V. V., Karlova, G. A., Kolesnikov, A. V., ByKoVA, N. V. \& GRAZHDANKIN, D. V. 2015. Revised Neoproterozoic and Terreneuvian stratigraphy of the Lena-Anabar Basin and north-western slope of the Olenek Uplift, Siberian Platform. Precambrian Research 270, 226-45.

Pojeta, J. \& RunNegar, B. 1976. The Paleontology of Rostroconch Mollusks and the Early History of the Phylum Mollusca. US Geological Survey Professional Paper 968, 88.

QIAN, Y. 1989. Early Cambrian Small Shelly Fossils of China with special reference to the Precambrian- Cambrian boundary. . In Stratigraphy and Palaeontology of Systemic Boundaries in China: Precambrian-Cambrian Boundary. pp. 1-341. Nanjing: Nanjing University Publishing House.

Qian, Y., Chen, M. \& Chen, Y. Y. 1979. Hyolithids and other Small Shelly Fossils from the Lower Cambrian Huangshandong Formation in the eastern part of the Yangtze Gorge. Acta Palaeontologica Sinica 18, 207-30.

Qian, Y., Zhu, M. Y., He, T. G. \& JiAng, Z. W. 1996. New investigation of PrecambrianCambrian boundary sections in eastern Yunnan. Acta Micropalaeontologica Sinica 13, 225-40.

Rowland, S. M., Luchinina, V. A., Korovnikov, I. V., Sipin, D. P., Tarletskov, A. I. \& Fedoseev, A. V. 1998. Biostratigraphy of the Vendian-Cambrian Sukharikha River section, northwestern Siberian platform. Canadian Journal of Earth Sciences 35, 33952.

Rozanov, A. Y., Missarzhevsky, V. V., Volkova, N. A., Voronova, L. G., Krylov, I. N., Keller, B. M., Korolyuk, I. K., Lendzion, K., Michniak, R., Pychova, N. G. \& Sidorov, A. D. 1969. The Tommotian Stage and the Cambrian lower boundary problem. Transactions of the Academy of Sciences of the USSR Nauka 206, 1-380.

Runnegar, B. \& Jell, P. A. 1976. Australian Middle Cambrian molluscs and their bearing on early molluscan evolution. Alcheringa 1, 109-38.

Runnegar, B. \& Pojeta, J. 1985. Origin and diversification of the Mollusca. In The Mollusca (eds E. R. T. a. M. R. Clarke). vol. 10: 1-57. Academic Press, Orlando.

Shaler, N. S. \& Foerste, A. F. 1888. Preliminary description of North Attleborough fossils. Harvard Museum of Comparative Zoology Bulletin 16, 27-41.

Steiner, M., Li, G., Qian, Y., ZhU, M. \& ERdTMAnN, B.-D. 2007. Neoproterozoic to Early Cambrian small shelly fossil assemblages and a revised biostratigraphic correlation of the Yangtze Platform (China). Palaeogeography, Palaeoclimatology, Palaeoecology 254, 67-99.

Ushatinskaya, G. T. \& Parkhaev, P. Y. 2005. Preservation of imprints and casts of cells of the outer mantle epithelium in the shells of Cambrian brachiopods, mollusks, and problematics. Palaeontological Journal 39, 251-63.

Varlamov, A. I., Rozanov, A. Y., Khomentovsky, V. V., Shabanov, Y. Y., Abaimova, G. P., Demidenko, Y. E., Karlova, G. A., Korovnikov, I. V., Luchinina, V. A., Malakhovskaya, Y. E., Parkhaev, P. Y., Pegel, T. V., Skorlotova, N. A., Sundukov, V. M., Sukhov, S. S., Fedorov, A. B. \& KipriYanova, L. D. 2008. Part 1: 
The Aldan-Lena Region. In The Cambrian System of the Siberian Platform, XIII International Field Conference of the Cambrian Stage Subdivision Working Group, Yakutia, Russia (eds A. Y. Rozanov and A. I. Varlamov). pp. 1-300. Moscow: PIN RAS.

Voronin, Y. L., Voronova, L. G., Grigorjeva, N. V., Drozdova, N. A., Zhegallo, E. A., Zhuravlev, A. Y., Ragozina, A. L., Rozanov, A. Y., Sayutina, T. A., Sysoev, V. A. \& Fonin, V. D. 1982. The Precambrian-Cambrian boundary in the geosynclinal areas (the reference section of Salany-Gol, MPR). Trudy Sovmestnoj Sovetsko-Mongol'skoj Paleontologirheslwj Ehkspeditsii, Nauka, Moscow 18, 1-150.

Voronova, L. G., Drozdova, N. A., Zhegallo, B. A., Zhuravlev, A. Y., Rozanov, A. Y., Sayutina, T. A. \& Ushatinskaya, G. T. 1987. Fossils of the Lower Cambrian of the MacKenzie Mountains (Canada). Trudy Paleontologicheskogo Instituta 224, 1-88.

XING, Y., Ding, Q., Luo, H., He, T. \& WAng, Y. 1984. The Sinian-Cambrian boundary of China and its related problems. Geological Magazine 121, 155-70.

YANG, B. 2014. Cambrian small shelly fossils of South China and their application in biostratigraphy and palaeobiogeography. In Department of Geosciences p. 164. Berlin: Freie Universität Berlin Berlin.

YU, W. 1987. Yangtze Micromolluscan fauna in Yangtze region of China with notes on Precambrian-Cambrian boundary. In Stratigraphy and Palaeontology of Systemic Boundaries in China. Precambrian-Cambrian boundary pp. 19-255. Nanjing University Publishing House.

Yu, W. 2014. On the Yangtzeconus priscus-Archaeospira ornata Assemblage (Mollusca) of the Earliest Cambrian of China. Acta Geologica Sinica - English Edition 88, 1262-87. 